\title{
19. SYNTHESIS OF NEOGENE EXPLOSIVE VOLCANISM OF THE TOHOKU ARC, DEDUCED FROM THE MARINE TEPHRA DRILLED AROUND THE JAPAN TRENCH REGION, DEEP SEA DRILLING PROJECT LEGS 56, 57, AND 87B 1
}

\author{
Kantaro Fujioka, Ocean Research Institute, University of Tokyo ${ }^{2}$
}

\begin{abstract}
Two different temporal patterns of explosive volcanism are represented in the reference stratigraphic sections of Sites 438 and 436, located, respectively, landward and seaward of the Japan Trench. The landward reference site shows two distinct maxima of the volcanic ash layers at approximately $16-15 \mathrm{Ma}$ and 5-2 Ma, a pattern common in the Tohoku Arc. The older maximum corresponds to the acidic volcanic activity in the Daijima and Nishikurosawa stages (16-15 Ma), which may be related to the formation of the Kuroko deposits. The younger maximum corresponds to the Funakawa and Kitaura stages (5-2 Ma), a time of prolific acidic volcanic activity and also of the intrusion of the so-called Tertiary granites related to the Dewa disturbance.

At the seaward reference site, the apparent frequency increase of the volcanic ash layers from 11 Ma toward the Recent was governed by the movement of the Pacific Plate with time, particularly the gradual approach of the site toward the volcanic source area, the Japanese Islands.
\end{abstract}

\section{INTRODUCTION}

During IPOD Legs 56 and 57 in 1977, the Glomar Challenger visited the Japan Trench forearc region off the Tohoku Arc and drilled at seven sites in different tectonic settings (Langseth et al., 1978; von Huene et al., 1978). In 1982, the ship revisited Japan and drilled at one site in the midslope of the trench (Leg 87B). Volcanogenic sediments are common in all the cores, as expected, because the sites are located downwind of the volcanic arc (Kennett, 1981; Machida, 1981; Machida and Arai, 1976).

Since the middle 1970s, debates about global explosive volcanism have highlighted the importance of problems related to paleoenvironment, glacial stage, and faunal extinctions (Kennett and Thunell, 1975; Ninkovich and Donn, 1976). IPOD sites in the Japan Trench provide one of the best field areas to solve these problems, for the following reasons:

1. The locations of two reference sites-one landward and one seaward of the trench, each on a different lithospheric plate-impart to each a unique history with regard to the volcanic source region.

2. Because their geologic histories differ, the sites' lithologies from the Cretaceous upsection also differ.

3. Grain size and the ratio of pumice content to bubble-wall glass shard content change regularly at Site 436 from bottom to top, that is, from the middle Miocene to the Recent.

4. Chemical compositions of the volcanic glass shards indicate that the provenance of the volcanogenic sediments was an island arc and/or an active continental margin, that is, the Tohoku Arc.

\footnotetext{
${ }^{1}$ Kagami, H., Karig, D. E., Coulbourn, w. T., et al., Init. Repts. DSDP, 87: Washington (U.S. Govt. Printing Office).

2 Address: Ocean Research Institute, University of Tokyo, 1-15-1 Minamidai, Nakanoku, Tokyo 164, Japan.
}

5. Frequency of occurrences and volume of the volcanic ash layers differ at each site.

This chapter summarizes geologic studies of the volcanogenic sediments collected from the reference sites, 438 and 439 (both landward) and 436 (seaward), and includes new information from drilling at Site 584. Inferences are based on the geology, accumulation rate, grain size, and chemistry of the volcanogenic sediment. The history of Neogene explosive volcanism of the Tohoku Arc and the concept of a global increase of the explosive volcanism (Kennett and Thunell, 1975) are discussed.

\section{GEOLOGY OF THE JAPAN TRENCH AREA}

The first systematic geologic investigations of the deep sea near Japan were undertaken by the Japanese Expedition for the Deep Sea (1959-1964, research vessel Ryofu Maru; see Nasu and Sato, 1962; Nasu et al., 1960; Nasu, 1964). These cruises generated considerable data about the Japan Trench region, and were followed by cruises of the Hakuho Maru of the Ocean Research Institute and the Hakurei Maru of the Japanese Geological Survey, which until 1975 accumulated measurements of gravity and heat flow, magnetic and seismic survey data, and sediment samples collected by dredge, grab sampler, and piston corer (Honza et al., 1977; Sato, 1973; Murauchi et al., 1978).

In 1977, during Legs 56 and 57, Glomar Challenger made the first deep penetrations into and beyond the Japan Trench sediment cover at Sites 438,439 , and 436 (Langseth et al., 1978; von Huene et al., 1978), establishing a rough outline of geologic history since the Cretaceous for both sides of the Japan Trench. Because questions about active-margin processes (e.g., tectonic accretion of sediments and rocks, the mechanism of dewatering, and the nature of the stress field around the forearc area) were not resolved, the Glomar Challenger returned in 1982 to drill at Site 584 (Leg 87) on the midslope between the deep-sea terrace and the trench axis. 
During this cruise, isoclinal beds were found to incline seaward by as much as $70^{\circ}$, dips too steep to be recorded by seismic profiler systems (Leg 87 Scientific Party, 1983).

\section{Location}

Locations of the sites drilled during Legs 56,57 , and 87B are shown in Figure 1, together with approximate bathymetry of the forearc area. Topographically, the sites can be classified into four groups: upper continental slope, middle trench inner slope, lower trench inner slope, and outer trench slope (Dickinson and Seely, 1979). Sites 438 and 439 are situated southeast of Hachinohe Knoll on the upper trench slope, a wide, gently sloping terrace as deep as $1600 \mathrm{~m}$. Sites 435,440 , and 584 are on the middle inner slope of the trench, and Sites 441 and 434 are on the lower slope.

Site 436 is east of the trench axis on the Pacific Plate. Horst and graben at this site bend with the Pacific Plate into the subduction zone under the Japanese Islands (Ludwig et al., 1966; Yoshii, 1979).

Four multichannel seismic profiling tracks are drawn perpendicular to the trench axis in Figure 1. The lines JNOC 1 and JNOC 2 and ORI 78-3 and ORI 78-4 were shot before drilling, as part of the presite surveys (Honza, 1980; Murauchi and Ludwig, 1980).

\section{Lithology}

Of the seven sites drilled in the Japan Trench area, two reached Cretaceous sedimentary rocks (Fig. 2). Cores recovered at Sites 438 and 439 (hereafter referred to as
Site 438) form a continuous overlapping sequence and reached sediments as old as the Cretaceous. Of all the sites, Site 438 is nearest to the Tohoku Arc and yielded a long sequence of continuous cores (Fig. 3). Accordingly, this site was treated as the landward reference site of the Japan Trench, and it was correlated biostratigraphically with the onshore Tertiary systems (Koizumi et al., 1980). Seven lithostratigraphic units were identified visually and petrographically (Shipboard Scientific Party, 1980a; Fujioka, 1983b). Unit 1 consists of olive gray coarse sand with erratic pebbles. The thickness of this unit varies from $107 \mathrm{~m}$ at Hole 438 to $52 \mathrm{~m}$ at Hole 438A. Diatoms are the major biogenic constituents of this unit. Quaternary sediments recovered in the Japan Trench area are also similar to this Unit 1 (Fujioka, Furuta, Kong, et al., 1980; Honza et al., 1977). Unit 2, 750 m thick, consists of dark olive gray, homogeneous, diatomaceous silty clay or mud, partly silicified in the lower part, with frequently acidic volcanic ash layers throughout. This unit is divided into three subunits. Near the boundary between Subunits $2 \mathrm{~B}$ and $2 \mathrm{C}$, calcareous concretions occur in a narrow interval. Dewatering structures are common in Subunit 2C.

Lithostratigraphic Unit 3 begins below an abrupt transition from diatomaceous mudstones to vitric sandy mudstone and some sandstone-siltstone beds. Microfaults, dewatering veins, and healed fractures are abundant, and fracturing and microbrecciation are intense. Unit 4 turbidites consist of dark gray beds. The sandstones are predominantly lithic arenite. Wood fragments, abundant detrital minerals, and reworked Cretaceous radiolarians

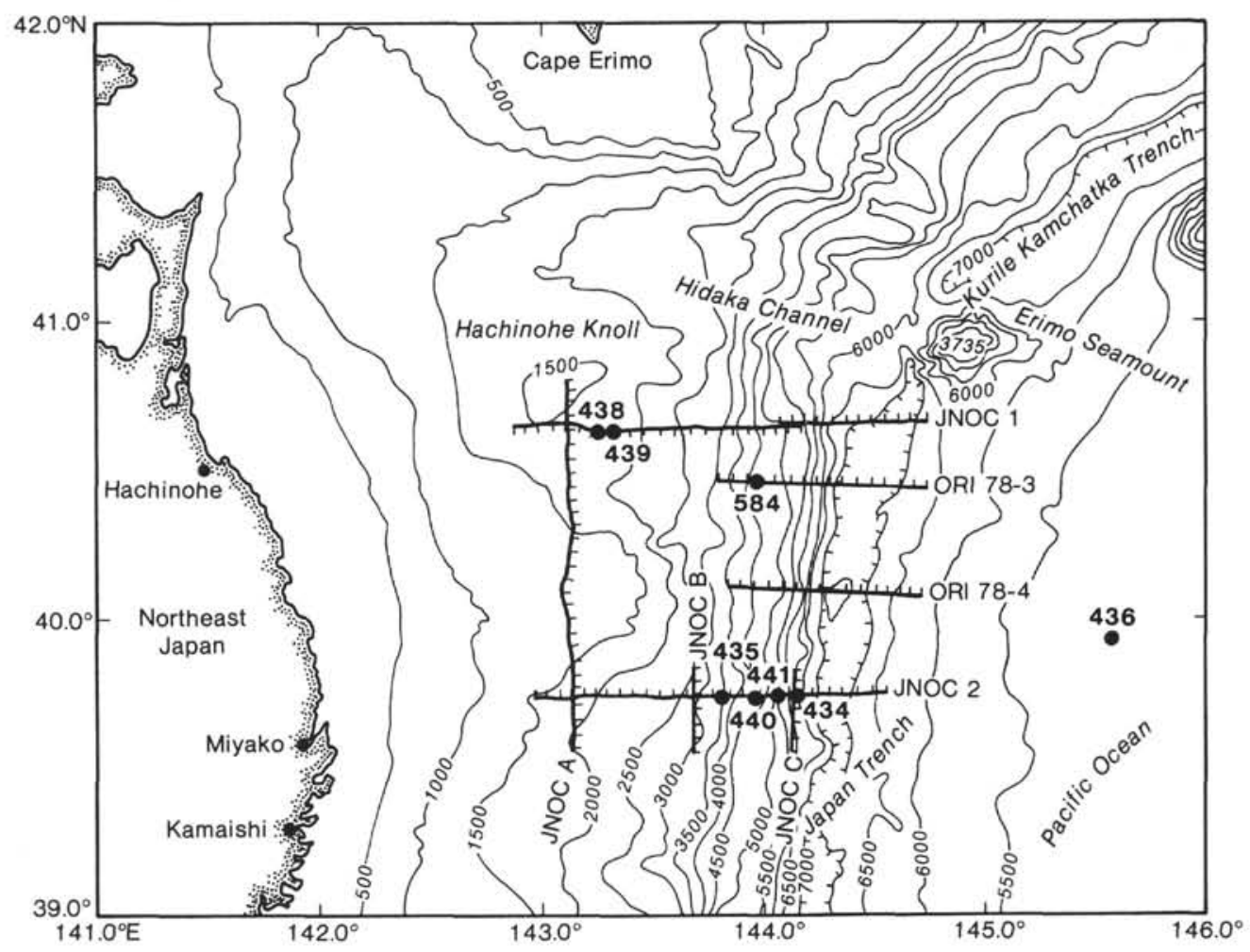

Figure 1. Location map of DSDP drill sites (solid circles) off the Tohoku Arc. Vertical and horizontal lines indicate the multichannel seismic profiles obtained during a presite survey by Japan National Oil Corporation (JNOC) and Ocean Research Institute (ORI), University of Tokyo. Bathymetry in meters. 


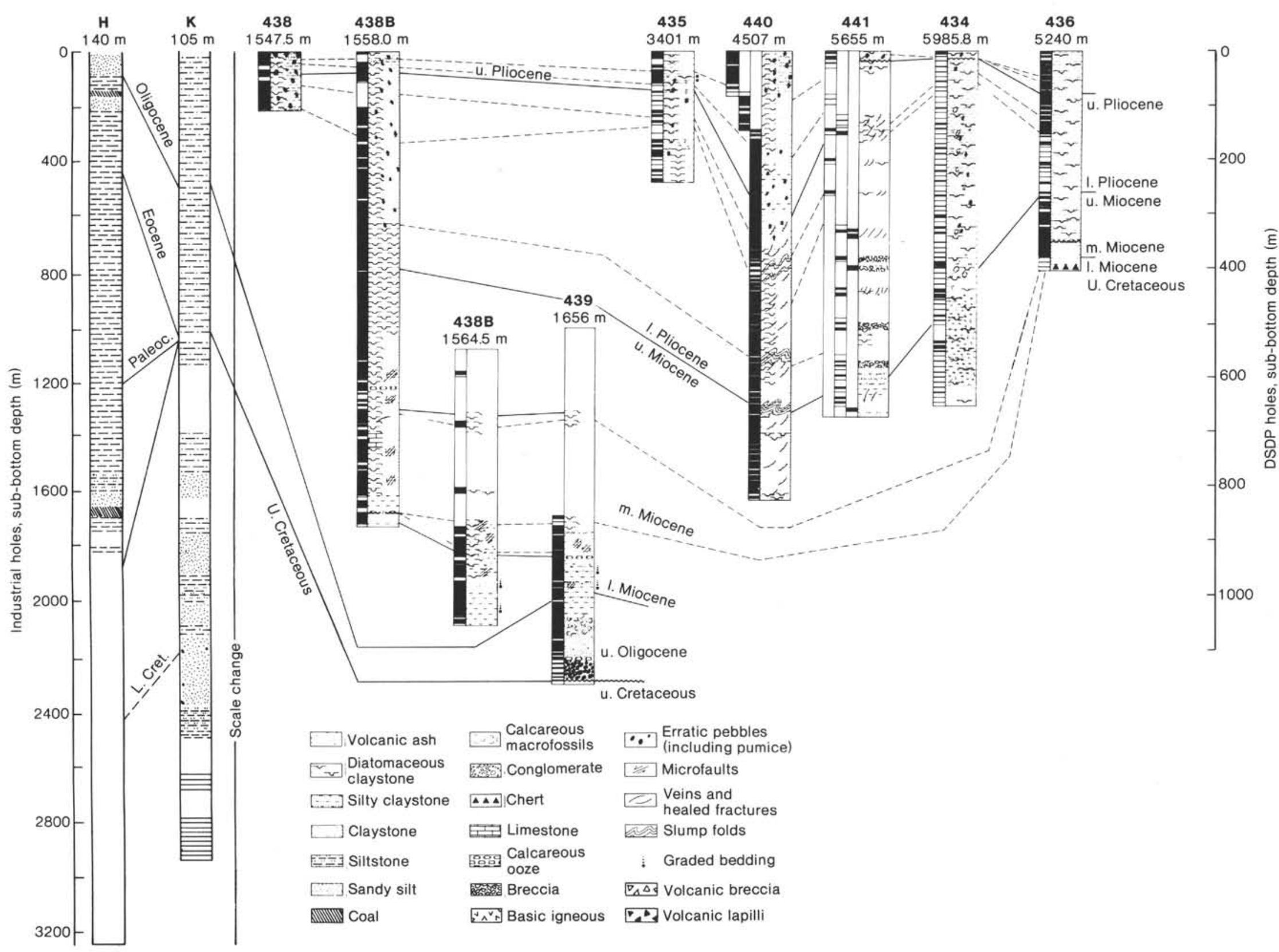

Figure 2. Lithologic columns of the drill sites in the Japan Trench area (after von Huene et al., 1982). Left side is west, and the trench axis lies between Sites 434 and 436 . Left columns $\mathrm{H}$ and $\mathrm{K}$ show the results of drilling of the continental shelf off Hachinohe and Kuji by the Teiseki Oil Company. Solid lines are the boundaries of ages correlated among the cores by biostratigraphy, and the broken lines show the biostratigraphic datum zones. Numbers at tops of columns (under hole numbers) give water depth of site. 


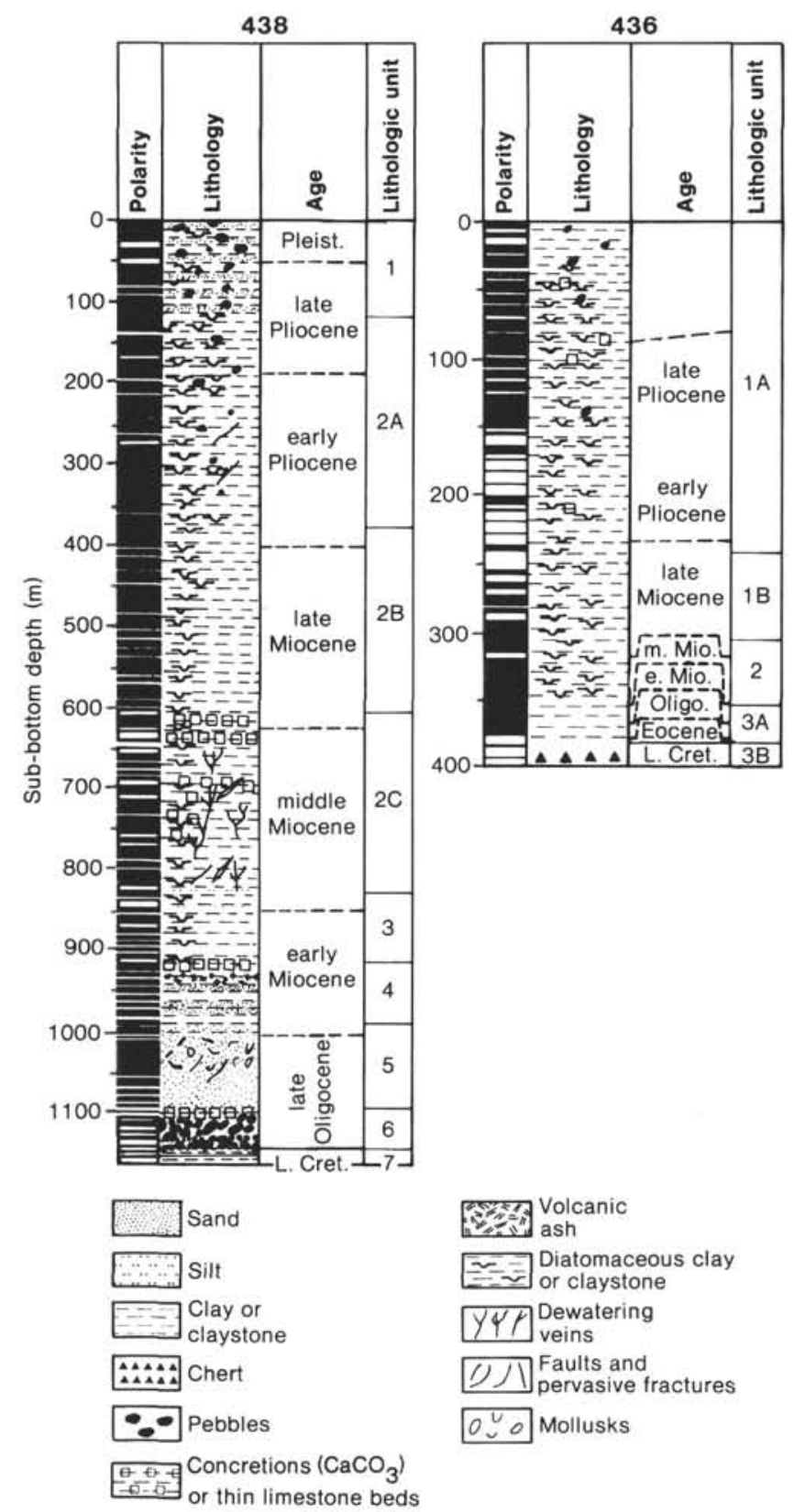

Figure 3. Schematic lithologic columns of reference sites in the Japan Trench region (Shipboard Scientific Party, 1980a, b). Site 438 here includes Site 439. Left columns for each site show recovery rates. Right columns show the lithostratigraphic units identified on board by visual inspection of cores. Age columns were determined by the microbiostratigraphy.

suggest erosion of basement identified in the multichannel seismic profiles. The top of the unit is marked by a $185-\mathrm{cm}$-thick homogeneous graded siltstone (Bouma sequence, Tae). Most of the other graded sequences are fine-grained turbidites from 10 to $80 \mathrm{~cm}$ thick.

Lithostratigraphic Unit 5 consists of massive, wellsorted sandstones and siltstones. Sedimentary structures are extremely rare in this unit. Articulated pelecypods and well-preserved gastropods are common. The sandstone is calcite-cemented lithic arenite. Lithostratigraphic Unit 6 is a 47.5 -m-thick conglomerate bed. The conglomerate contains angular to subrounded clasts from granule to boulder size (maximum 65 -cm diameter). Clasts consist almost totally of light bluish gray to gray green intermediate to acidic volcanic rocks derived from the island arcs and active continental margins (Miyashiro, 1974, 1975; Fujioka, 1980). In the matrix of the conglomerate, there are no marine fossils. Dating by ${ }^{39} \mathrm{Ar} /$ ${ }^{40} \mathrm{Ar}$ indicates an age of $23.4 \pm 5.5 \mathrm{Ma}$ (Moore and Fujioka, 1980) and $22.2 \pm 0.7,22.5 \pm 1.3$, and $22.8 \pm$ 1.5 Ma (Yanagisawa et al., 1980).

This basal conglomerate's constituents, granules and angular clasts of monolithologic composition, its nonmarine fossils, and its magnetic properties all indicate deposition on land-the Paleogene "Oyashio ancient landmass" (von Huene et al., 1978; Shipboard Scientific Party, 1980a) - after a short eruption of the calc-alkalic rocks (Fujioka, 1980; Fujioka and Nasu, 1978). Below this unit, only $12.5 \mathrm{~m}$ of dark gray silicified siltstone, Unit 7, was drilled. Unit 7 represents local acoustic basement, below an unconformity that marks a long hiatus (Late Cretaceous to latest Oligocene)..

The lithologic section of the seaward reference Site 436 is divided into three units (Fig. 3). Units 1 and 2 consist of dark olive gray diatomaceous mud, including various amounts of sand in Unit 1 . These units resemble Units 1 and 2 of the landward reference Site 438. Lithostratigraphic Unit $3 \mathrm{~A}$ consists of moderately brown to brownish black pelagic clay intercalated by manganese micronodules. Neither calcareous nor siliceous microfossils were found in this unit. Only ichthyoliths were found, and they correlate with the early Miocene, Oligocene, and Eocene. No terrigenous sediment was deposited in this unit (Langseth et al., 1978; Shipboard Scientific Party, 1980b; Lancelot and Larson, 1975).

Acoustic basement, represented by the strong reflectors in the multichannel seismic profiles, lies beneath Unit $3 \mathrm{~A}$. A long hiatus exists between Unit $3 \mathrm{~A}$ and acoustic basement, which yields Cenomanian-Albian radiolarians. This hiatus was widely identified in other DSDP cores of the western Pacific area (Shipboard Scientific Party, 1980).

\section{Accumulation Rates}

At these two sites, 438 and 436 , microfossils, especially diatoms, were generally well preserved. Diatom biostratigraphy compiled both on board (Barron, 1980; Barron et al., 1980) and on shore (Koizumi et al., 1980) provides precise age determinations. Accumulation rate curves and absolute sedimentation rates are based mainly on this diatom biostratigraphy (Arthur et al., 1980). Despite this precision, the diatom biostratigraphic zonation scheme is not yet fully resolved, and debates continue in the published literature (Akiba, 1982). During Leg 87B, good cores for diatom biostratigraphy were obtained, and Akiba (this volume) settled complicated problems regarding diatom datum planes and introduced some new zones, such as the Thalassionema schraderi Zone. Basically, Barron's work (Barron, 1980) remains intact, especially as regards the Denticulopsis seminae and $D$. kamtschatica zones.

Two periods of maximum accumulation rate of terrigenous sediment occurred at Site 438 (Fig. 4): 16-14 Ma and 5-2 Ma. Between 14 and $5 \mathrm{Ma}$, accumulation rates 

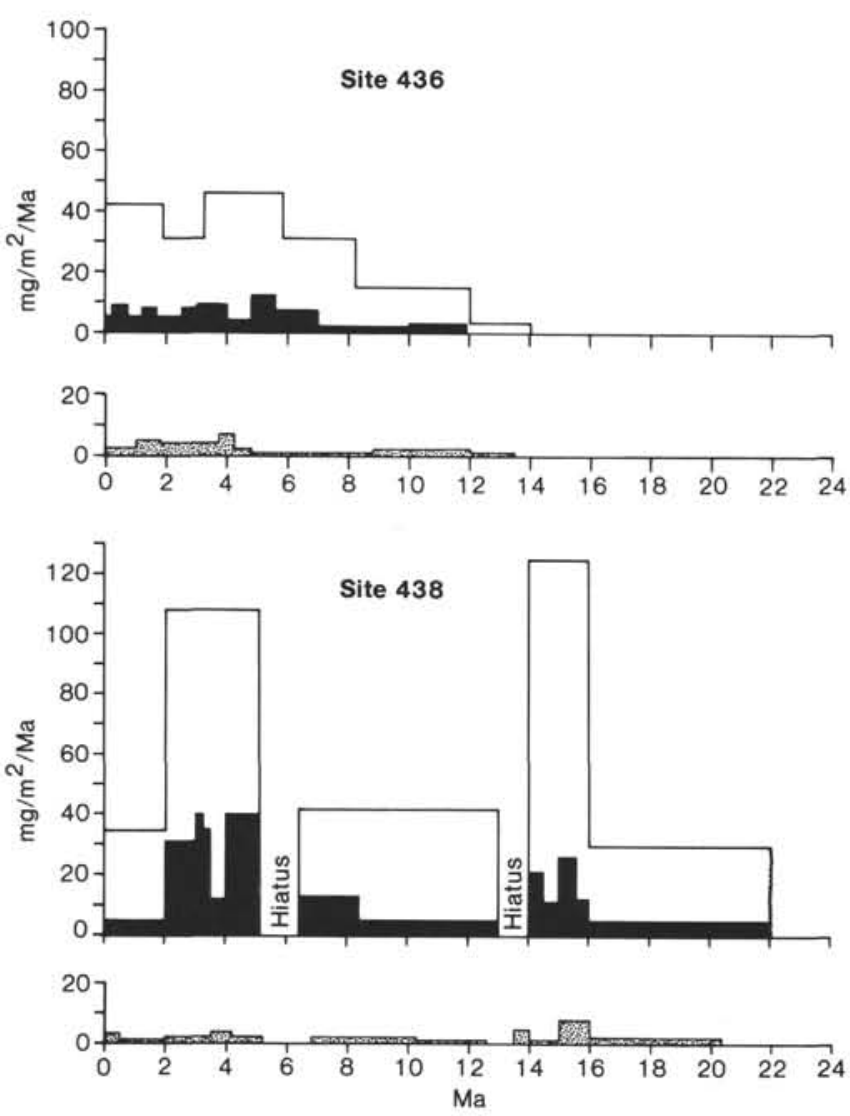

Figure 4. Accumulation rates of terrigenous materials, biogenic silica (diatoms), and volcanogenic materials in sediments at Sites 438 and 436 (Arthur et al., 1980). No pattern-terrigenous materials; shaded block - biogenic silica; stippled pattern-volcanogenic materials. Note two maxima of the terrigenous input at 16-15 Ma and 5-2 $\mathrm{Ma}$ in diagram for Site 438. No definite maxima are apparent for Site 436 , only a gradual overall increase of the terrigenous materials from $14 \mathrm{Ma}$ to the Recent.

of the terrigenous component are about half the maximum rates. Two short hiatuses exist around 6 and $13 \mathrm{Ma}$. The accumulation rate of biogenic silica (mainly diatoms) has a pattern similar to that of the terrigenous sediment. On the other hand, the accumulation rate of the terrigenous component at Site 436 increases gradually from about $14 \mathrm{Ma}$ to the Recent without any definite maximum.

\section{Geologic History}

Paleodepth of each site was estimated using benthic foraminiferal assemblages (Keller, 1980). The paleoenvironments estimated by paleodepth and lithology differ drastically at the two sites (Fig. 5). Site 438 was part of a landmass where an Upper Cretaceous mudstone with slump structures was deposited and where dacitic volcanism took place shortly before subsidence in the latest Oligocene. The resulting volcanic rocks were deposited as the basal conglomerates relative to the overlying sequences. In the earliest Miocene, this site was in a shallow shelf environment where surf sand with gastropods and bivalves accumulated. Then the site began to deepen by as much as $1600 \mathrm{~m}$ even as turbidite beds were deposited.

During the deposition of Unit 2, in Pliocene time, the site was much deeper than the calcite compensation depth
(CCD), as judged from the absence of such calcareous fossils as foraminifers and nannofossils. The depth of this site at that time was perhaps deeper than $2500 \mathrm{~m}$ (Keller, 1980; Langseth et al., 1980). Toward the end of Pliocene, the site began to rise gradually, and probably reached its present depth of $1600 \mathrm{~m}$. Therefore, the landward reference site represents mainly the vertical movements related to subduction of the Pacific Plate under the Tohoku Arc (Fujioka, 1983a).

The paleoenvironment of Site 436, in contrast, was controlled mainly by horizontal movements. After deposition of Cretaceous radiolarian ooze beneath the CCD in a region that no terrigenous sediment could reach, a long hiatus occurred (Fujioka, 1983b; Lancelot and Larson, 1975; Shipboard Scientific Party, 1980b). Although accumulation rates are low with respect to the total thickness of this unit, the lithology changes gradually upsection. Terrigenous materials began to mix with the pelagic sediments, and the accumulation rate increased until, in the Quaternary, sediments at this site became similar to those at Site 438 (Fujioka, 1983b). The depositional environments of this site from Cretaceous to the present remained beneath the CCD.

The geologic histories of the two reference sites contrast because of the convergence of the Pacific and Eurasian plates. The different histories are also recorded in the nature of the volcanogenic sediments deposited at these sites.

\section{VOLCANIC ASH LAYERS}

Volcanogenic sediments are in various degrees products of the volcanic activity of active continental margin, of intraplate volcanism, or of submarine volcanism. They are distributed to the lee of island arcs (Lisitzin, 1972; Vallier and Kidd, 1977; Kennett, 1981) by the global wind system (Fig. 6) and mixed with the terrigenous, biogenic, and authigenic components to form marine sediments containing volcanogenic material in excess of 50\% (Horn et al., 1969). The Japan Trench lies on the leeward side of the Quaternary volcanic front of the Tohoku Arc, so the prevailing westerlies blow tephra into this region. Quaternary sediments obtained by piston corers include volcanic ash layers correlatable with known subaerial events, such as the Towada tephra obtained off Hachinohe (Fujioka, Furuta, Kong, et al., 1980).

Machida (1981) summarized the distribution of major tephra around the Japanese Islands according to the measured refractive index of glass shards included in the tephra (Fig. 7), and identified several great eruptions during the last 20,000 years. These marine sediments preserve the record of explosive volcanism that took place on shore, and tephrochronology is one of the most powerful tools for dating these geologic events.

\section{Debate about Global Explosive Volcanism}

Since the first report of volcanic ash layers recovered from the Atlantic Ocean floor (Bramlette and Bradley, 1941), many marine geologists have reported ash layers as critical time-markers of synsedimentary events (Bowles et al., 1973; Ninkovich and Shackleton, 1975); and since the start of DSDP, marine evidence for global explosive 

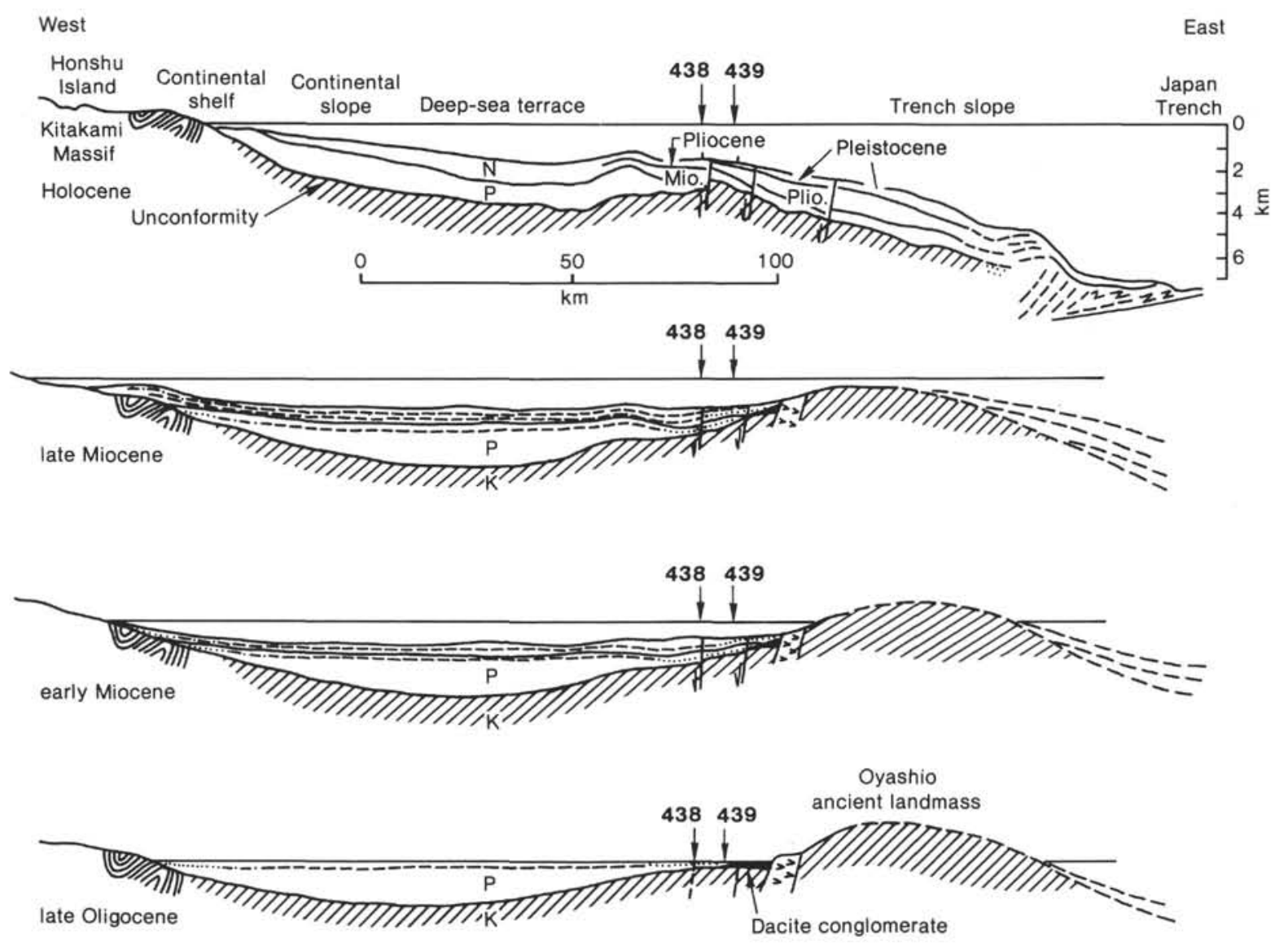

Figure 5. Schematic diagram showing proposed evolution of the Japan Trench continental margin from the late Oligocene to Recent (Shipboard Scientific Party, 1980a). Note the uplifted Oyashio landmass during the early Cenozoic and its subsequent rapid subsidence. $\mathrm{K}=$ Cretaceous; $\mathrm{P}=$ Paleogene; $\mathrm{N}=$ Neogene.

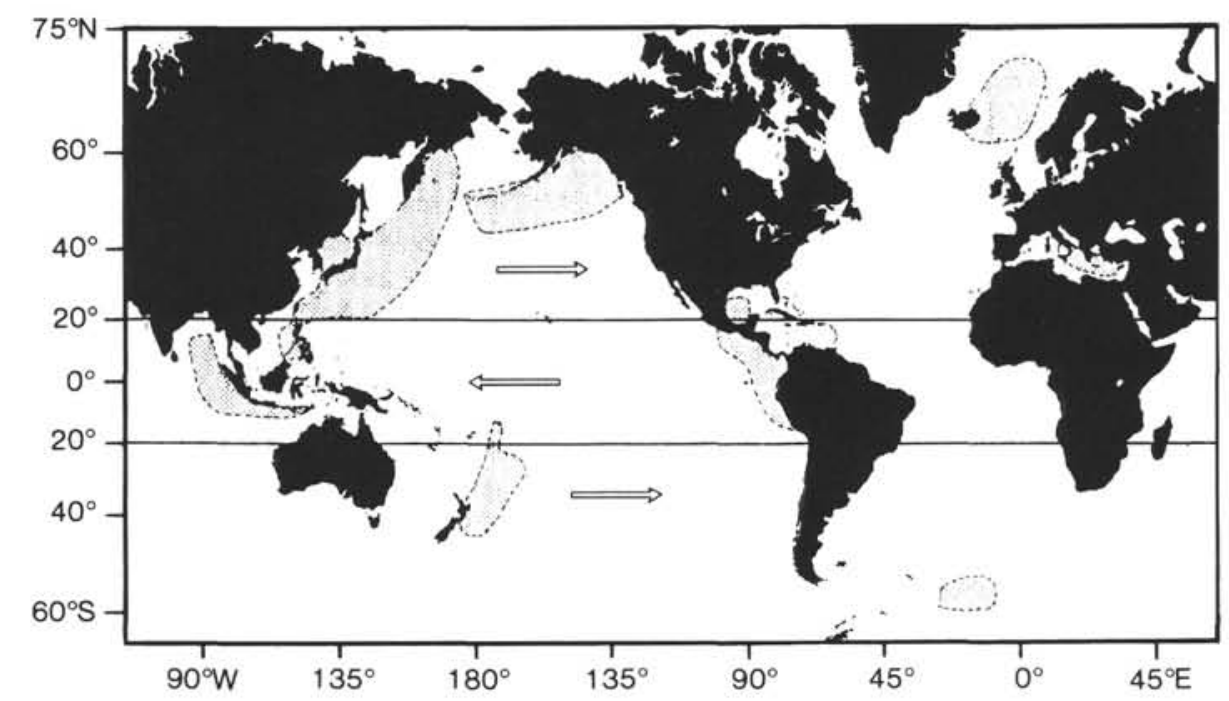

Figure 6. Global wind system and distribution of volcanogenic sediments on the ocean floor (Kennett, 1981).

volcanism throughout the Tertiary has been gathered by numerous workers (Kennett, 1981). In the 1970s, Kennett's group, who were compiling data on volcanic ash layers and ashy sediments obtained by DSDP, demonstrated from the ashy sediments and biostratigraphic ages of foraminifers that explosive volcanism increased worldwide during the Quaternary; they discussed the close relationship among volcanic activity, geomagnetic reversals, climatic change, and faunal extinctions (Kennett and Thunell, 1975; Kennett and Watkins, 1970). Their 


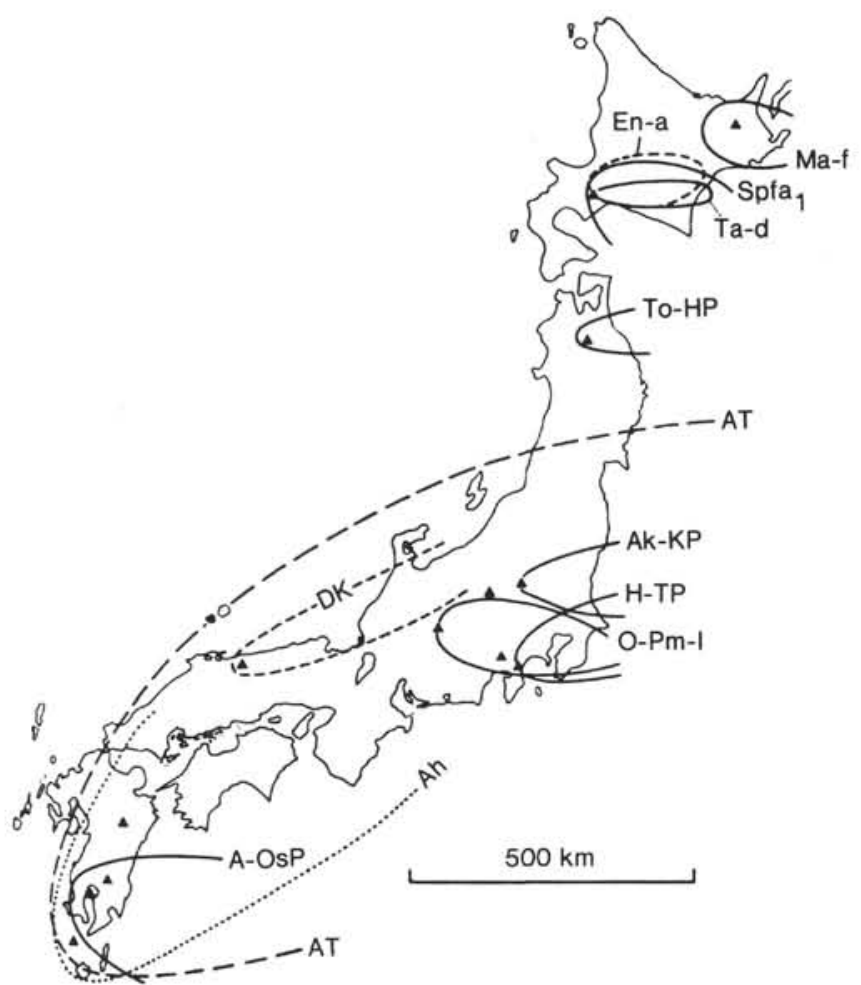

Figure 7. Distribution of the major tephra around the Japanese Islands (modified from Machida and Arai, 1976). En-a, Ma-f, Spfa Ta-d, To-HP, AT, DK, Ak-KP, H-TP, O-Pm-l, Ah, and A-OsP are the marker tephra. Solid triangles show active volcanoes, and the lines show the limit of the distribution of the marker tephra.

work influenced many volcanologists and marine geologists. When Kennett and Thunell (1975) published histograms of the frequency of volcanic ash layers above and below artificial time planes, DSDP was not coring continuously. Cores obtained from the Japan Trench are continuous, however, so that one need not evaluate the numbers of volcanic ash layers using artificial factors. Average recovery generally exceeds $60 \%$, and locally exceeds $80 \%$. In this chapter, no special coefficient was applied to obtain a corrected frequency. Cadet and Fujioka (1980) compiled Neogene tephra obtained from the Japan Trench region and drew frequency curves for each site, estimating the correction factors on the frequency diagram. The two sets of results are in good agreement.

Investigating the same problems, Ninkovich and Donn (1976) found that the older sediments recovered by DSDP contained few volcanic ash layers, and that only some piston cores gathered from Indonesia contained volcanic ash layers. They presented instead a moving-plate model in which, as DSDP sites approach volcanic source areas, ash-layer frequencies generally appear to increase toward the Quaternary-the pattern obtained by Kennett and Thunell (1975). This first-order problem can be investigated by comparing frequency patterns of the tephra obtained at two different sites-each in the lee of a source region, each on a different lithospheric platewith one site fixed relative to the tephra source region and the other moving toward the source region. Sites 438 and 436 meet those conditions.

\section{Mode of Occurrences of Three Types of Volcanic Ash Layers}

Several hundred volcanic ash layers occur in the cores obtained during Legs 56,57 , and $87 \mathrm{~B}$. Volcanogenic layers show various shapes on the cut surfaces of the archive core halves. They are divided into three major types according to their mode of occurrence in the cores (Fig. 8).

1. Type L. A definite layer with sharp upper and lower boundaries cutting completely across the core. The thickness of a given ash layer is not always constant.

2. Type P. An ashy block or mass having a podlike or pocketlike shape. Actual shapes vary; they are sometimes ragged, sometimes stretched in various directions.

3. Type D. A dispersed tephra, not visually identifiable, especially common in active margins. The proportion of these glass shards is usually less than $10 \%$, but sometimes exceeds $10 \%$. Types $\mathrm{L}$ and $\mathrm{P}$ tephra always contain more than $30 \%$ volcanic material, and rarely more than $90 \%$ volcanic glass shards. Type D tephra have more than $10 \%$ volcanic glass shards plus phenocryst minerals. If the supply rates from eolian fallout of volcanic ash are high enough, Type $L$ rather than Type D tephra will usually form. But if conditions such as strong currents or steep bottom topography dominate and retard deposition of the volcanogenic component, Type $\mathrm{P}$ or Type D may form. Even after deposition of the definite tephra layers, bottom-dwelling organisms may destroy the primary bedding, forming the ashy bioturbites observed at Site 584 (site chapter, Site 584, this volume). Such organisms are not well known, but Chondrites, Zoophycos, and Planolites are the most familiar. Ashy sediments may play an important role in estimating the degree of bioturbation, because the effects of deformation are readily visible. Postdepositional deformation, dewatering, healed fractures, folding and faulting, and rotary drilling may disturb the volcanic ash layers. Turbidity
A

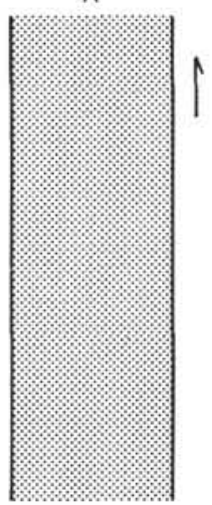

B

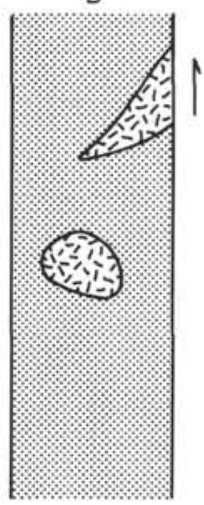

C

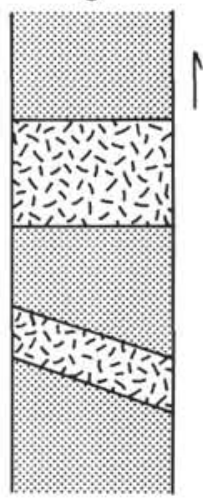

Figure 8. Schematic diagram for three types of volcanic ash observed in DSDP cores. A. D type (dispersed type). B. P-type (pod or pocket type). C. L type (layer type). Arrows show the direction upward in the section. 
currents also destroy the original structures. Therefore, definite Type $\mathrm{L}$ volcanic ash layers are rare.

\section{Frequency Diagram}

To obtain frequencies, we were able to use a new method for counting volcanic glass shards (Huang et al., 1975) and the smear-slide descriptions, which provide a measure of the concentration of the shards in relation to age. Arthur, von Huene, and Adelseck (1980) constructed a diagram of such data, showing the percentage of the dispersed volcanic glass shards in sediments from Site 438,440 , and 441 . Their results are similar to those presented herein (Fig. 9). At Site 438, periods of maximum concentration of tephra layers occurred at 16-15 $\mathrm{Ma}$ and 5-2 Ma. Between these two intervals (i.e., from 15 to $5 \mathrm{Ma}$ ), the frequency was quite low. This general pattern resembles the accumulation rates calculated for Site 438 (Fujioka, 1983a). Evidently, explosive volcanism took place many times during a very short term within these two periods.

The pattern obtained for Site 436 differs from that for Site 438. No record of explosive volcanism is preserved from before $11 \mathrm{Ma}$, when Site 436 was located far from the Japanese Islands. Frequency tends to increase gradually toward the Quaternary, in harmony with the sedimentation rate pattern calculated for this site (Fujioka, 1983a).

At Site 438, hiatuses between 5.5 and $6.7 \mathrm{Ma}$ and between 12.3 and 13.7 Ma prevent conjecture about the frequency of volcanism within these two intervals; from the other data, however, it appears that the frequency was not very high.

\section{Discussion}

The distance between Site 438 and the source region is thought to have remained constant at about $200 \mathrm{~km}$ throughout the Neogene. The volume of a volcanic ash layer is represented as $S \times d \mathrm{~cm}^{3}$, where $S$ is the cross-

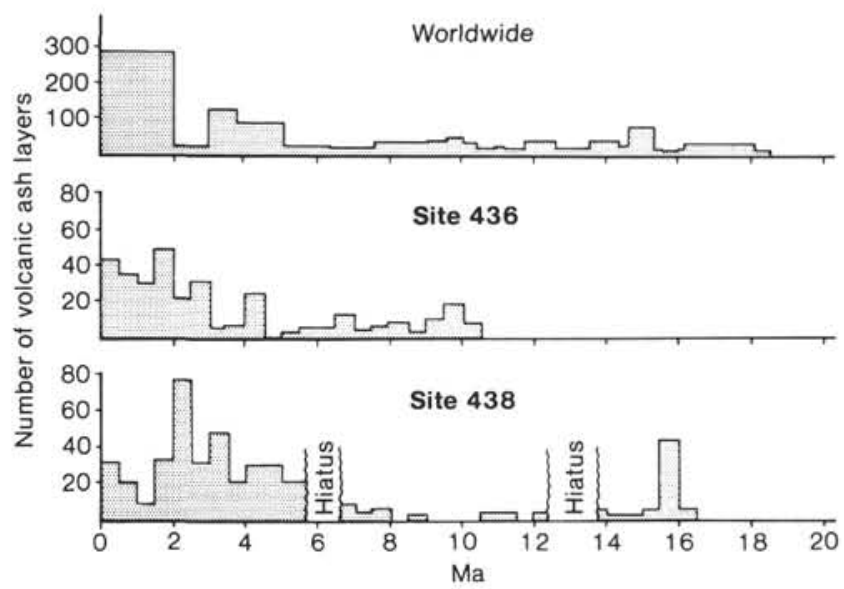

Figure 9. Frequency of the volcanic ash layers versus age. The upper row shows the pattern of the worldwide volcanic ash layers (Kennett and Thunell, 1975). The middle one is obtained from Site 436 on the Pacific Plate. Note the similarity to the worldwide pattern. The lower plot shows the pattern characteristic of the onshore Tohoku Arc. The patterns for Sites 436 and 438 are similar to the sedimentation rate patterns for those sites (Fig. 4). sectional area of the core and $d$ is the thickness of the ash layer. Because the core diameter is constant, the volume can be expressed as a thickness factor. To obtain the true thickness, we must take into account the effects of sediment compaction. Arthur, Carson, and von Huene (1980) measured the bulk density of the sediment samples and also interpreted in situ density logs. Near the surface, the density of diatom-rich mud is about 1.3-1.5 $\mathrm{g} / \mathrm{cm}^{3}$, but near the top of the section at Site 439 , the value is about $1.7-1.8 \mathrm{~g} / \mathrm{cm}^{3}$, owing to compaction by the overlying sediments. Huang and others (1979) measured the experimental compaction effect using dry, dated Minoan Tephra; the thickness reduced to about $50 \%$ of the original thickness. If water saturates the sediment, conditions become very complicated.

Adopting the result of Arthur, Carson, and von Huene (1980) and assuming only vertical compaction, we must take into account a volume loss of about $25 \%$ (Fig. 10).

\section{PETROGRAPHY AND GRAIN SIZE OF VOLCANIC GLASS SHARDS \\ METHODS}

Volcanic ash layers were visually identified on board Glomar Challenger and sampled for their petrography and chemistry. The IPOD sampling method uses tube samplers, so that some vertical contamination of sediments is inevitable. The clay fraction was removed using an ultrasonic cleaner. After the samples were washed, smear slides were prepared for petrographic descriptions and heavy minerals were separated for analysis, using Clelici and tetra-bromo-ethane liquids with specific weights of about 2.64 .

The samples were examined with the binocular microscope and the petrographic microscope. Also, microstructures of individual volcanic glass shards were examined by scanning electron microscope (SEM).

\section{Observation under Binocular Microscope}

Plates 1 and 2 show stereographic photographs of pumice-type and bubble-wall-type glass shards, fecal pellets, and lithic fragments. In Sample 436-34-3, 22-24 cm, fecal pellets were examined in detail. Thompson and Whelan (1980) have described four types from Site 436. Fecal pellets vary considerably in size, but are generally coarser than the glass shards. The degree of fecal pellet contamination of the volcanic ash layers increases downsec-

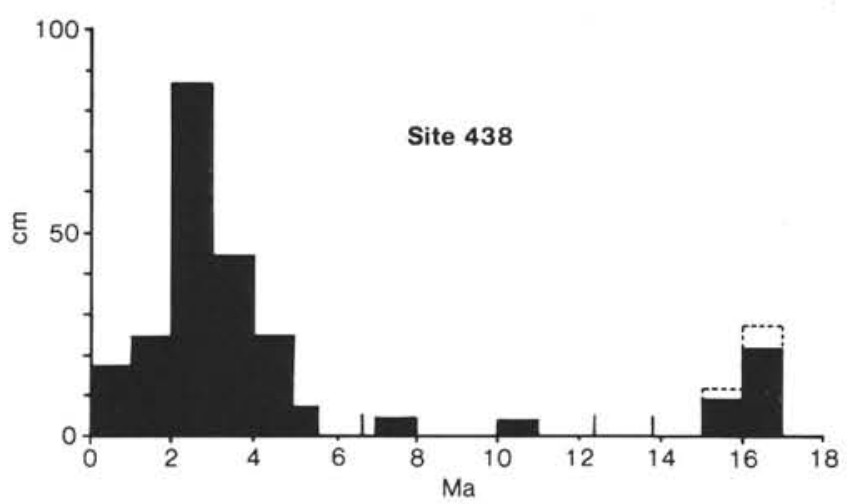

Figure 10. Histogram of the summation of the thickness of the volcanic ash layers versus age. The pattern is similar to the frequency diagram of Figure 9. Broken lines show the thickness recalculated to take into account the compaction of overlying sediments. 
tion at Site 436, and is particularly high in an interval of slow accumulation in Unit $3 \mathrm{~A}$. As has already been shown in the previous chapter, accumulation rates of the terrigenous component increase upsection at Site 436, and commonly-if the sedimentation rate is low-contamination by other material is relatively high.

\section{Smear-Slide Examination}

Smear slides of the volcanic ash layers were examined after the samples had been washed and the clay minerals eliminated by ultrasonic cleaning. Dry samples were mounted on glass slides using Canada balsam $(n D=$ 1.498). Examined under the petrographic microscope, volcanic ash layers may be seen to include both pumicetype and bubble-wall-type volcanic glass shards, quartz, feldspar, clinopyroxene, orthopyroxene, hornblende, biotite, magnetite, fecal pellets, biogenic matter, and lithic fragments.

Both types of glass, as well as round palagonites, are transported as terrigenous components and sometimes as altered pumice glass. Amounts of these two components are minor, however, compared with the two major glass types. The ratio of pumice to the bubble-wall shards was measured under the microscope. The ratio at Site 438 varies layer by layer, displaying no regular pattern with respect to sub-bottom depth. The same ratio for Site 436 , however, shows a regular pattern from top to bottom. The $P /(P+B)$ ratio increases gradually upsection, along with the grain size of the tephra. This means that younger tephra were deposited nearer to their source. The volcanic glass shards are translucent and colorless, perfectly isotropic under the microscope, and free of secondary alteration. The thermal gradient at Site 438 is about $3^{\circ} \mathrm{C} / 100 \mathrm{~m}$, which is accordant with that of highpressure metamorphic terrains (Miyashiro, 1972a, b; Fujioka, Furuta, and Arai, 1980). Opal-CT occurs in some intervals below $1000 \mathrm{~m}$ at Site 438 , and in some radiolarians clinoptilolite has crystallized from the wall to the center (Matsumoto and IIjima, 1980).

\section{Phenocryst Minerals}

Tephra always contain variable percentages and assemblages of phenocryst minerals. Crystal-to-glass ratios of tephra are also variable and deflect distance from the source region (Huang et al., 1979; Carey and Sigurdsson, 1978). The crystal shape of mafic minerals such as clinopyroxene, orthopyroxene, hornblende, and biotite are euhedral and sometimes subhedral, but rarely anhedral. Plagioclase crystals are strongly zoned from core to rim. The origin of the quartz is sometimes very difficult to judge. Some quartz is a sedimentary contaminant of the volcanic ash layers. Some assemblages of phenocryst minerals show that the original rock was a two-pyroxene dacite-biotite rhyolite, a common type in active continental margins and island arcs (Miyashiro, 1974, 1975).

\section{Refractive Index of Volcanic Glass Shards}

Refractive index was measured for some tephra layers, using the method of Fujioka, Furuta, and Arai (1980). The range of the indices at each site is $1.498-1.511$, re- flecting dacitic and rhyolitic chemical compositions (Kittleman, 1973).

\section{Grain Size}

Grain-size analyses were carried out using several methods. Fractions coarser than 4 phi were sieved through stainless steel meshes of each phi scale and the dry samples mechanically weighed (Fig. 11). The fraction finer than 4 phi was analyzed using the photo-extinction method with a hydrophotometer (Jordan et al., 1971).

Grain sizes were also measured directly in smear slides under the binocular microscope. Those grain sizes are defined by the expression $\sqrt{(a) \times(b)}$ where $(a)$ is the length of the long axis and $(b)$ is the length of the short axis, and are shown in conventional cumulative curves in Figure 12.

The grain-size distribution of the volcanic ash layers changes considerably from layer to layer and is an important parameter in determining the source area of the tephra (Fig. 11). Distribution patterns are similar to those obtained by Murai (1963) and Fisher (1963) for the pyroclastic fall deposits, and the sorting coefficient is low (Fig. 12). Some modes for Site 436 samples are in the coarser size fraction, owing to the contamination by the generally larger fecal pellets within the volcanic ash layers. Median phi values of the Site $\mathbf{4 3 8}$ samples are much coarser than those of the Site 436 samples (Fig. 11), and grain size becomes gradually coarser upsection at Site 436.

\section{Discussion}

In terms of the characteristic features of tephra, summarized by Matsuda and Nakamura (1970), these samples are air-air-water type (AAW) air-fall tephra. The $P / B$ ratios and increase in grain size of the volcanic glass shards trace the approach of Site 436 toward the Japanese Islands. Median phi values at each site may reflect the positions of the source regions of the volcanic ash layers. Results strongly indicate that the provenance of the tephra was the Tohoku Arc.

\section{CHEMICAL COMPOSITION OF THE VOLCANIC GLASS SHARDS \\ ANALYTICAL METHODS}

Chemical compositions of the volcanic ash layers were measured by wet-bulk analysis, using the conventional X-ray refraction fluorescence (XRF) method and the electron probe micro-analyzer (EPMA). A glass dish is prepared for XRF analyses as follows: $1.0000 \mathrm{~g}$ of dried volcanic ash is powdered in a tungsten carbide bowl mill grinder and then weighed precisely. Five times as much dilithium tetraborate is added as a flux, and the mixture is then fused in a conventional furnace at temperatures up to $1000^{\circ} \mathrm{C}$. A JCXA-733 superprobe and a JXA-5 were used for EPMA analysis of the volcanic glass shards and the phenocryst minerals. The ash was softly crushed between the fingers and washed in an ultrasonic cleaner. Glass shards and heavy minerals were then separated by heavy liquid; the shards were impregnated with epoxy resin, and polished thin sections were prepared. Experimental conditions for analyses were $15 \mathrm{kV}, 100 \mathrm{~mA}$ at a $20 \mu \mathrm{m}$ beam diameter. The chemical analysis was carried out with an automatic analyzer after checking the homogeneity.

\section{Homogeneity}

Samples of five major Quaternary tephra, collected at various locations around the Japanese Islands, were 

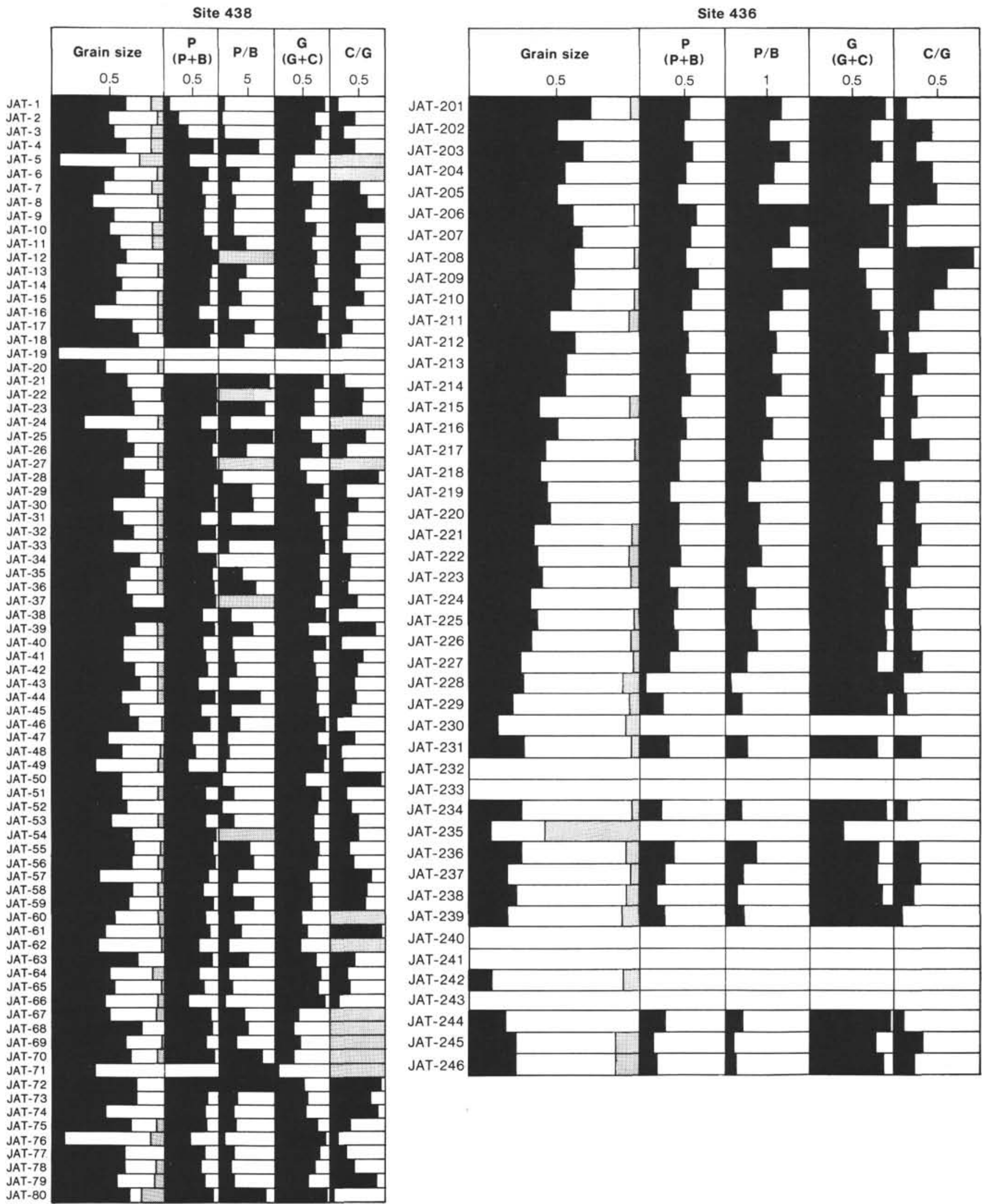

Figure 11. Grain size and the following ratios of the volcanic ash layers: pumice-type glass to pumice-type glass plus bubble-wall-type glass, pumicetype glass to bubble-wall-type glass, glass to glass plus crystal, and crystal to glass. Grain size is divided into sand/silt/clay, $\mathrm{P}=$ pumice-type glass shard; $\mathrm{B}=$ bubble-wall-type glass shard; $\mathrm{C}=$ crystal; $\mathrm{G}=$ Glass. Note the gradual increase in sand component as well as $\mathrm{P} / \mathrm{B}$ ratio at Site 436. 

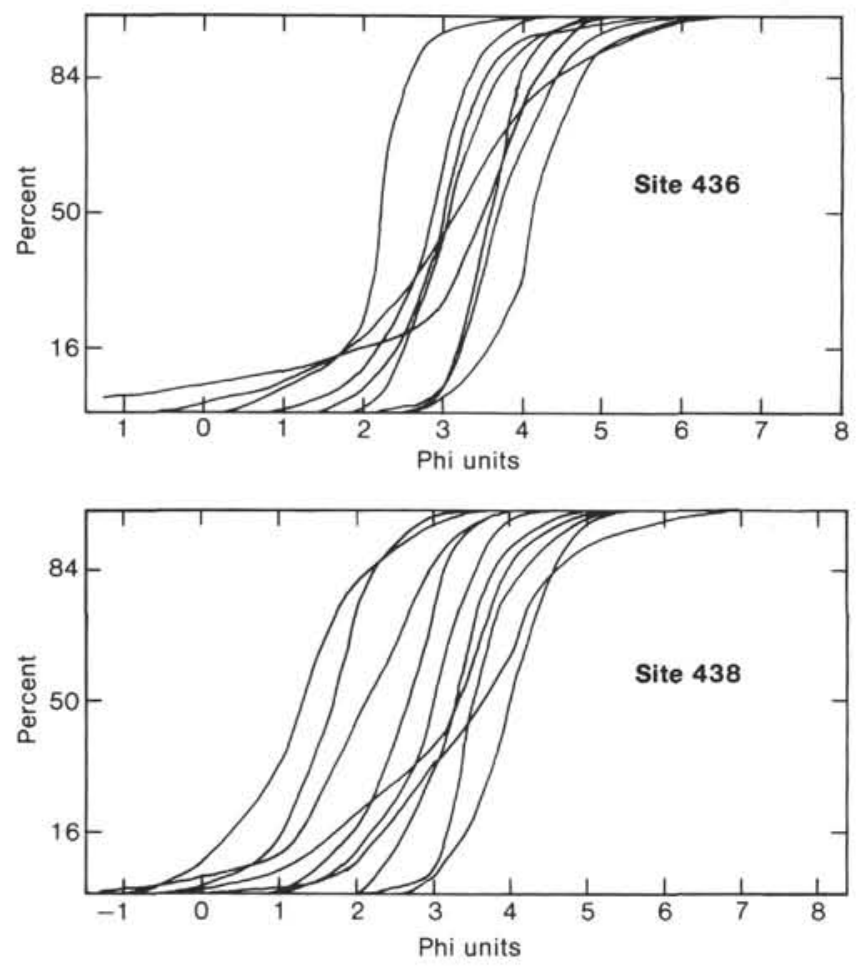

Figure 12. Cumulative curves of grain size of the volcanic ash layers.

analyzed with the JXA-5 probe for their degree of hydration and alteration. The water content of volcanic glass is about $5-6 \%$. One of these glasses, Akahoya, the most widely distributed tephra around the Japanese islands, was examined using more than ten piston cores obtained from various parts of the ocean floor. The major-element measurements of more than 50 analyses of this one ash layer are in good accord for each element. So if hydration took place after eruption of that layer, it has not been intense enough to change the major-element compositions. The marine environment changes neither the major nor the minor elements. However, various elemental changes, described for subaerial samples, do result from the composition of the groundwater attached to the glass shards. After deposition, halmyrolysis, or low-temperature alteration in the marine environment, and devitrification can change the chemical distribution of each element in a glass shard, so these problems were also checked. If chemical leaching of some elements in the shards occurs, scanning patterns of one glass may decrease in intensity near the grain periphery. Shards at least as old as the middle Miocene, however, show no differences in chemical scanning pattern and chemical photographs anywhere within the grain, whereas those older than the middle Miocene have some peripheral changes in elemental composition (Fujioka, Furuta, and Arai, 1980).

\section{Compositional Diagrams}

More than 100 volcanic ash layers were chemically analyzed for the volcanic glass shards to find a suitable correlation method or factor. Chemical analyses are plotted on $\mathrm{SiO}_{2}$ versus $\left(\mathrm{Na}_{2} \mathrm{O}+\mathrm{K}_{2} \mathrm{O}\right)$ diagrams for classi- fication of the volcanic rock series (after Kuno, 1960, 1966). Volcanic glass shards from both Site 438 and Site 436 fall into the non-alkalic rock-series category on a water-free basis, according to the boundaries between alkalic and non-alkalic fields drawn in Kuno's original curve (Fig. 13). There are no alkalic rocks in the Japan Trench volcanogenic deposits. The $\mathrm{SiO}_{2}$ content ranges from about 65 to $75 \%$, corresponding to rocks of dacitic to rhyolitic composition, in agreement with the refractive index data for these volcanic glass shards.

$\left(\mathrm{Na}_{2} \mathrm{O}+\mathrm{K}_{2} \mathrm{O}\right)-\mathrm{MgO}-\mathrm{FeO}$ (AMF) and $\mathrm{Na}_{2} \mathrm{O}-\mathrm{CaO}-$ $\mathrm{K}_{2} \mathrm{O}$ diagrams for all the compositional data reveal similar trends between tephra from Site 438 and those from Site 436 (Fig. 14). The distribution of data points in the $\mathrm{Na}_{2} \mathrm{O}-\mathrm{CaO}-\mathrm{K}_{2} \mathrm{O}$ diagrams corresponds to the pattern expected for the calc-alkalic rock series and/or tholeiitic series, which predominate in island arcs and active continental-margin settings. The similarity of the volcanic glass shard compositional trends indicates a common source in the Tohoku Arc and the possibility of correlating tephra layers between the two sites.

\section{GEOLOGY OF THE TOHOKU ARC}

If the sea level rises as much as $200 \mathrm{~m}$, the morphology of the Tohoku Arc would resemble the typical double arc (Miyashiro, 1967). What was the geology of the Tohoku Arc during the Neogene? Neogene systems of the
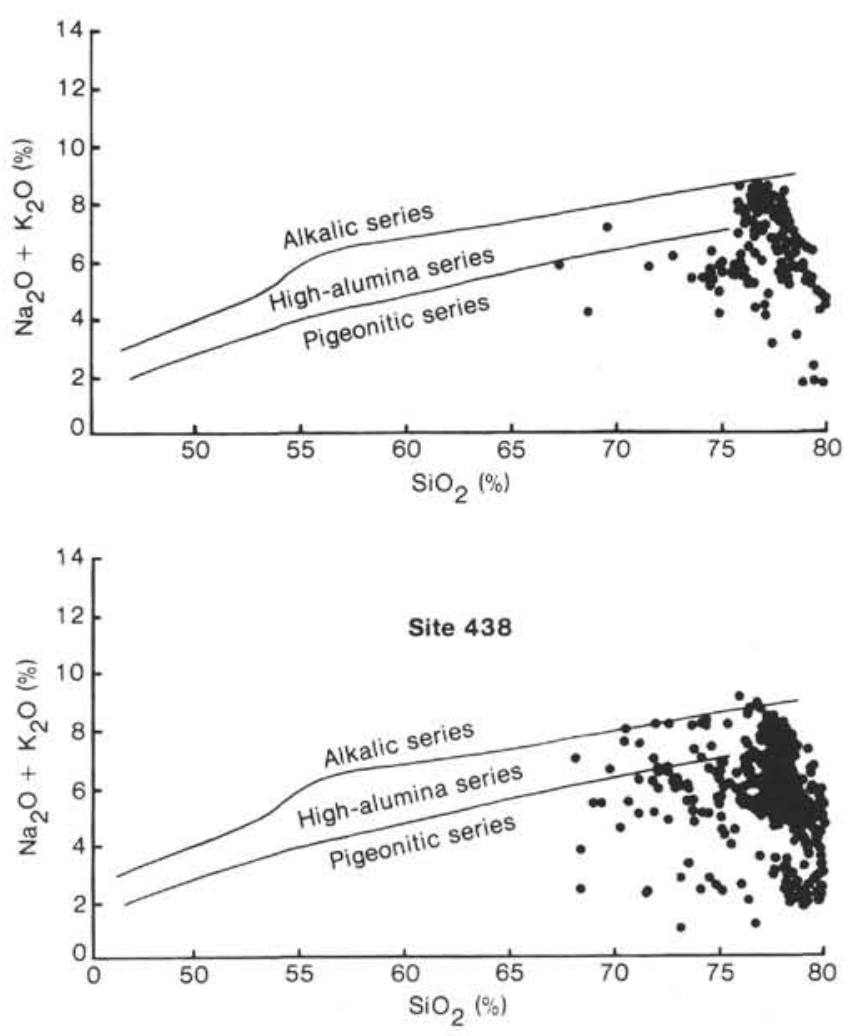

Figure 13. $\mathrm{SiO}_{2}$ versus $\left(\mathrm{Na}_{2} \mathrm{O}+\mathrm{K}_{2} \mathrm{O}\right)$ diagrams for the volcanic glass shards analyzed by EPMA. Data are plotted on water-free basis recalculated as $100 \%$. Except for a few samples, all the data fall into the non-alkalic regions. Lines are boundaries between basaltic types (as shown) from Kuno (1965). 

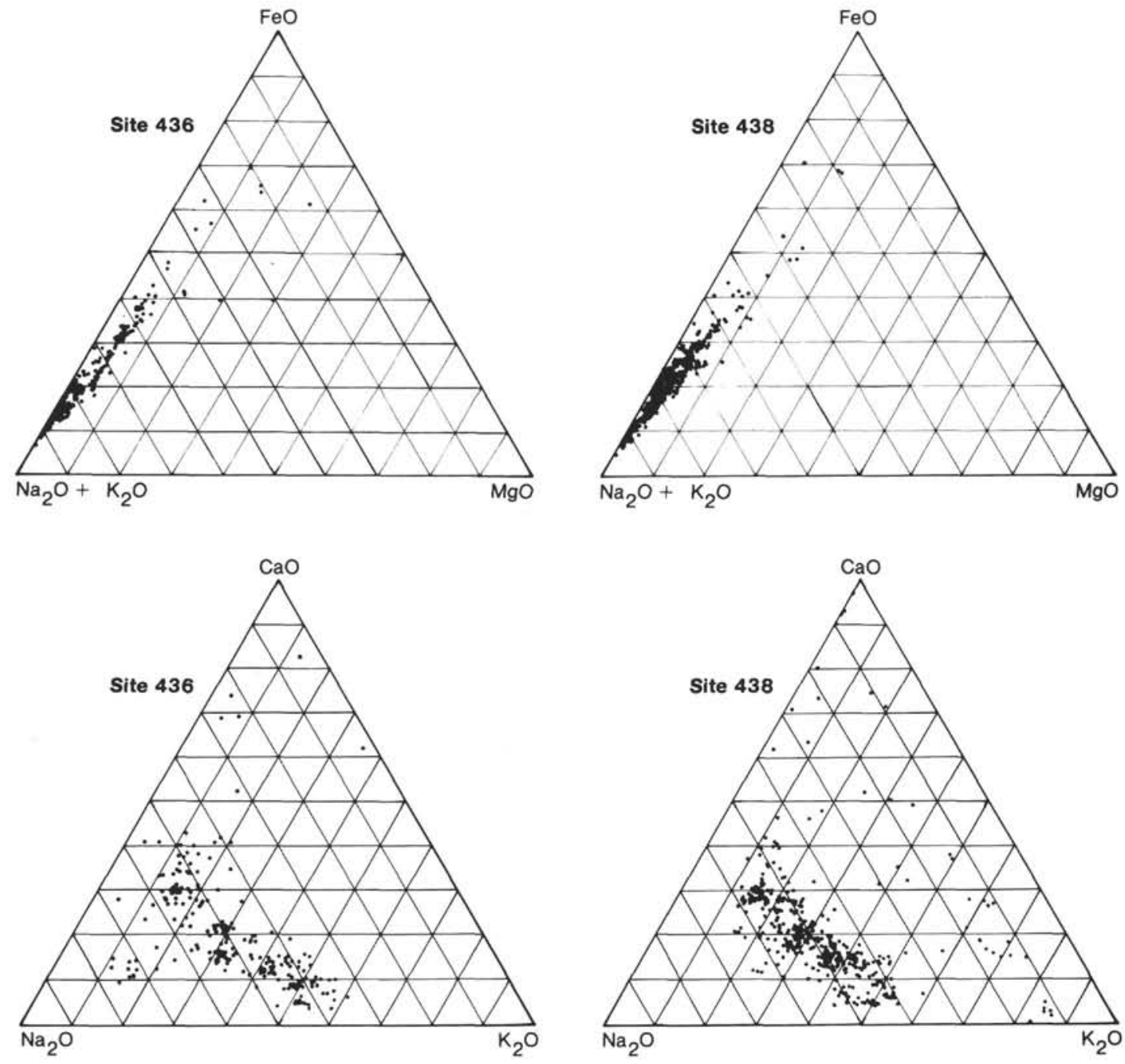

Figure 14. Comparison of the volcanic glass shards in $\mathrm{AMF}$ and $\mathrm{Na}_{2} \mathrm{O}-\mathrm{CaO}-\mathrm{K}_{2} \mathrm{O}$ plots. Note the similarity between the two sites in these diagrams.

Tohoku Arc contain abundant volcanogenic green tuff (Fig. 15). Sugimura and others (1963) related the volume of Tertiary volcanic materials to the Mizuho Orogeny. Matsuda and others (1967) and Kitamura (1959) described the regional geology and compiled the orogenic history of the Tertiary Tohoku Arc in terms of the geosynclinal evolution model. Later, Ikebe (1962) focused on the western part of the Tohoku Arc and related the geosynclinal model to oil geology. Matsuda and others (1967) summarized the characteristics of the Tertiary Mizuho Orogeny in the Tohoku Arc. Matsuda and Uyeda (1971) treated this arc as a product of the Pacific Orogeny. In the context of plate tectonics, Uyeda and Miyashiro (1974) discussed the regional volcanism and plutonism taking place around the Japanese Islands and the Sikhote Alin area in terms of subduction of the KulaPacific Ridge, during pulsations of movement of the $\mathrm{Pa}$ cific Plate. Kanamori (1971) proposed the slab evolution model, treating several subduction zones, such as the Aleutian, the Tohoku, and the Izu-Mariana arc trench systems. He proposed the cyclic evolution of subducting oceanic plates. Dickinson (1973) discussed the migra- tion of the arc-trench gap with time. Niitsuma (1978) applied Kanamori's theory to the orogeny of the Tohoku Arc. Recently, Amano $(1981,1983)$ discussed the orogeny of the Tohoku Arc in terms of plate tectonics and eustatic sea-level changes. Because the Tohoku Arc is considered a "typical subduction zone," debates about its evolutionary history are of interest to the international community of earth scientists.

Apart from these lines of conjecture, numerous debates about the origin, environment, and stratigraphic control of metal deposits (like the Kuroko deposits, massive sulphide ore deposits of the Nishikurosawa Formation and its equivalents) involved mining geologists.

\section{Summary of Neogene Volcanism of the Tohoku Arc}

The history of volcanic activity of the Tohoku Arc has been summarized by many authors in relation to the orogeny and the Kuroko metallogeny. First, Huzioka (1956) reviewed the so-called green tuff. Later on, Ozawa (1963) and Sugimura and others (1963) discussed volcanism and volume change of the Tohoku Arc volcanic materials . Kitamura (1959) noted that acidic volcanism 


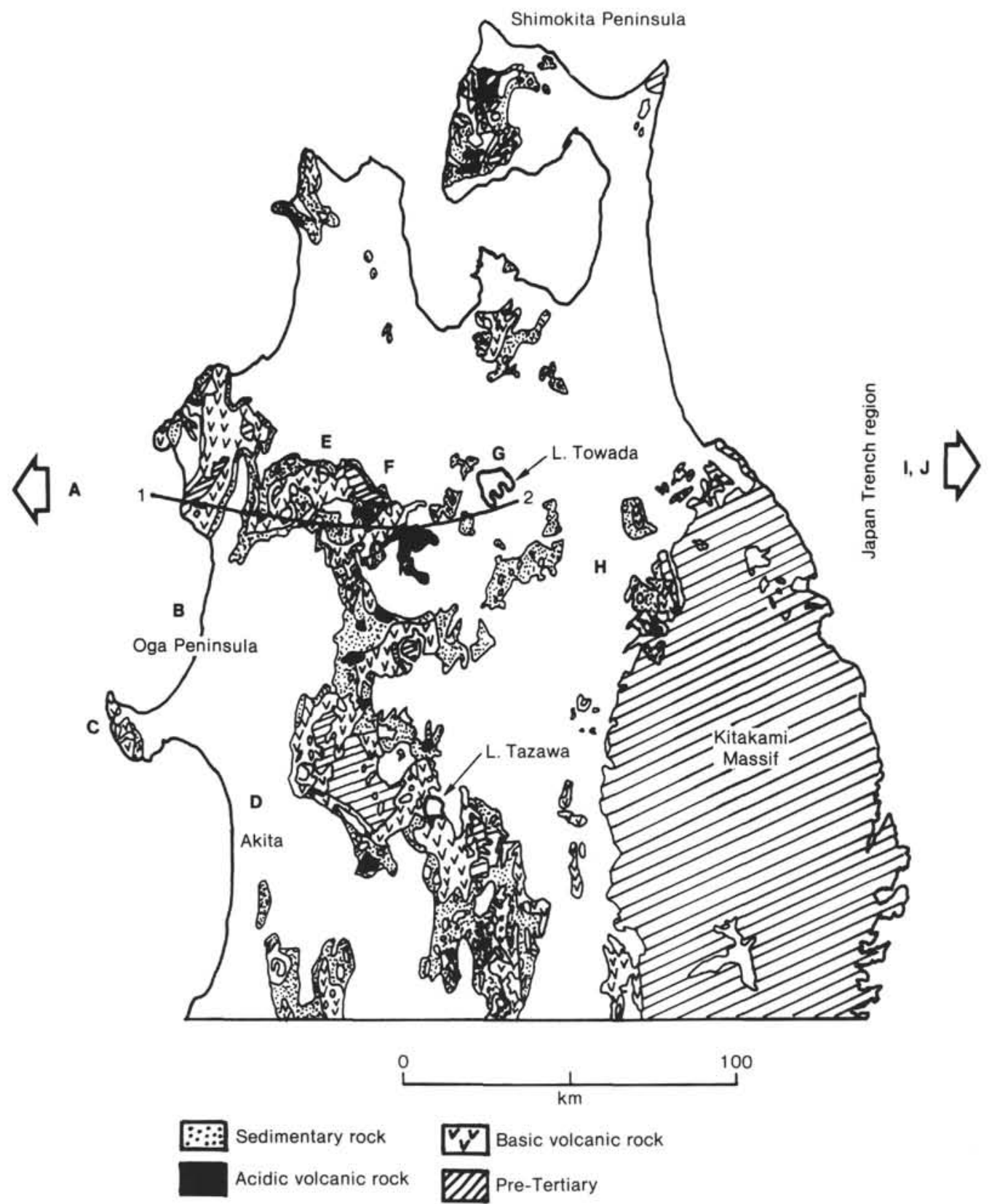

Figure 15. Lithologic distribution of the Nishikurosawa Formation and its equivalents. Stratigraphy of regions A through $\mathbf{J}$ is listed in Figure 16.

is controlled by the stratigraphic horizons in the backbone range. Konda (1974) hypothesized "bimodal volcanism" of the Tohoku Arc during the Onnagawa Stage. Horikoshi $(1975,1976)$ pointed out the concentration of the Kuroko deposits in the Nishikurosawa Stage and compiled the volcanic history of the Tohoku Arc. Ishihara (1974) summarized the Neogene volcanic activities in relation to the Kuroko metallogeny. Fujioka (1983a) compiled the correlation of the stratigraphy and magmatic evolution of the Tohoku Arc using the standard stages of the Tohoku Arc (Huzioka, 1956; Takayasu and Matoba, 1976). Evidently, the style of volcanic activity has changed as follows: first, the Monzen Stage of andesite and high-alumina basalt; second, the Daijima Stage of dacitic and rhyolitic pyroclastic flow deposits of the calcalkalic series; third, the Nishikurosawa Stage of submarine basaltic volcanism in the west and acidic volcanism of the calc-alkalic series in the east; fourth, the Onnagawa Stage of dacitic volcanism and basaltic bimodal volcanism; fifth, the Funakawa and Kitaura stages of dacitic volcanism and Tertiary granitoids; and finally, the Quaternary andesitic volcanism.

Regional acidic volcanism took place only during the Daijima-Nishikurosawa stages and the Funakawa-Kitaura stages. Recent advances in micropaleontology allow compilation of the major stratigraphic correlations across the Tohoku Arc. Fujioka (1983b) compiled and correlated all the stratigraphic units across the Tohoku Arc along 
$40^{\circ} \mathrm{N}$, from the Sea of Japan to the Japan Trench (Fig. 16). According to this compilation, and taking into account $\mathrm{K}-\mathrm{Ar}$ and ${ }^{39} \mathrm{Ar}-{ }^{40} \mathrm{Ar}$ radiometric age determinations for some of the volcanic rocks (Konda and Ueda 1980; Kaneoka, 1983; Tsuchi, 1979), acidic volcanism is concentrated in the intervals between 16 and $15 \mathrm{Ma}$ and 5 and $2 \mathrm{Ma}$ (Fig. 16). These intervals accord with the frequency maxima of the volcanic ash layers obtained from the Japan Trench sediments, indicating that the wind system during the Tertiary was the same as during the Quaternary, namely prevailing westerlies.

Petrologic studies were carried out for the acidic volcanic rocks belonging to these two periods. Kawano and others (1961) described many acidic volcanic rocks of the Tohoku Arc, mainly Quaternary volcanoes such as Nasu and Chokai. Kuno $(1960,1966)$ and Sakuyama (1979) discussed the variation of magma composition across the island arc, showing the results for the Tohoku Arc; more recently, Togashi (1983) discussed the chemical compositions of the Neogene volcanic rocks.

The chemical compositions of the acidic volcanic rocks of the Daijima-Nishikurosawa stages are of the calc-alkalic series dacitic to rhyolitic, including two pyroxenes and hornblende, and biotite as phenocryst minerals (Tatsumi and Clarke, 1972). The chemical compositions of the acidic volcanic rocks belonging to the Funakawa and Kitaura stages are mostly calc-alkalic-series pyroclastic rocks related to the Tertiary granitoids yielding the many vein-type ores of the Tohoku Arc.

\section{Discussion}

The pattern of Tertiary explosive volcanism revealed at various locales on the Tohoku Arc is preserved in the volcanic ash layers deposited offshore of the Tohoku Arc. Sedimentation of the forearc region is continuous compared with that of the Tohoku Arc, although even offshore there are two short hiatuses at $5 \mathrm{Ma}$ and $11 \mathrm{Ma}$. The marine sediments are accurately dated using biostratigraphic age scales and datum zones for the major groups of marine microfossils.

\section{Tectonics during Two Periods}

Regional acidic explosive volcanism predominated during the Daijima-Nishikurosawa stages (16-15 Ma) and the Funakawa-Kitaura stages (5-2 Ma). The environment of the older maximum period was similar to that of the present-day Izu-Ogasawara arc-trench system (Fig. 17), if we judge from the morphotectonic configuration across the Tohoku Arc during that period (Fujioka, 1983a).

The Oga Peninsula was a volcanic island, the Akita oil field was a trough of moderate depth, and the Takanosu area was a group of seamounts; the Hokuroku district was a fault-bounded depression in which acidic volcanic domes occupied the central part and were closely related to formation of the Kuroko deposits; the Sekiryo (backbone range) was a volcanic front supplying ash layers to Sites 438 and 436 , and the Sannohe region was a continental shelf. This cross section is similar to the present-day cross section of the Izu-Ogasawara arc-trench system across about $31^{\circ} \mathrm{N}$. Tamaki (in press) hypothesized the existence of the back-arc depressions just behind this volcanic arc, and, on the basis of morphotectonic similarity between the Tohoku Arc and the IzuOgasawara Arc, Fujioka (1983b) proposed that the present-day Kuroko may have been depositing sediment in this depression. A tensional tectonic stress field prevailed in the Tohoku Arc during the Nishikurosawa to Onnagawa stages (Nakamura and Uyeda, 1980; Takeuchi, 1981), a structural configuration analogous to the "Mariana-type" mode of subduction (von Huene and Uyeda, 1980; Uyeda, 1982; Niitsuma, 1978).

Active uplift, related to the Tertiary granitoids and vein-type ore deposits, occurred in the Funakawa and Kitaura stages (Horikoshi, 1975). Paleogeography was like that of the Andes mountain region, and uplift was from east to west during the Funakawa and Kitaura stages. Huzioka (1968) called this the "Dewa Disturbance," relating it to oil transport in the reservoir and to the orogenic periods of the Kitaura Stage. Regional acidic volcanism generated pyroclastic flows and fall deposits all over the Tohoku Arc. The regional stress field changed to compressional and the mode of subduction became "Chilean" instead of "Mariana-type" (Uyeda, 1982). However, uplift of Site 438 was delayed until about 3 Ma.

The origin of the regional acidic volcanism has been discussed by many petrologists, but no definite consensus exists. Many petrologists accept the importance of the role of a volatile component within the magma and the resultant formation of much more acidic magmas. Changes of subduction mode may control the supply rate of water from both the sediments and the dehydration products of hydrous materials.

\section{SUMMARY AND CONCLUSIONS}

The volcanogenic sediments drilled at two different sites in the Japan Trench during Legs 56 and 57 were examined for lithology, sedimentation rate, sedimentary structure, mode of occurrence of the volcanic ash layers, petrography, grain-size distribution, and chemical composition. The results are summarized as follows:

1. The geologic history of Site 438 was controlled mainly by vertical movements, that of Site 436 by horizontal movements. This contrast results from the location of Site 438 (and the Tohoku Arc) on the Eurasian Plate and that of Site 436 on the Pacific Plate moving toward the Tohoku Arc.

2. Both sites yield many volcanic ash layers in various modes of occurrence, and although they vary considerably in thickness, layers at Site $\mathbf{4 3 8}$ are generally thicker than those at Site 436.

3. At Site 438 , two definite peaks in the frequency of occurrence of volcanic ash layers occur at 16-15 Ma and 5-2 Ma, but the pattern at Site 436 is one of a gradual increase in frequency from $11 \mathrm{Ma}$ to the Recent. These two patterns match the patterns of terrigenous sedimentation rate at these sites.

4. The grain size of the Site 438 tephra is much coarser than that of the Site 436 tephra. At Site 436 , both the grain size and the $P / B$ ratio of the glass shards change 


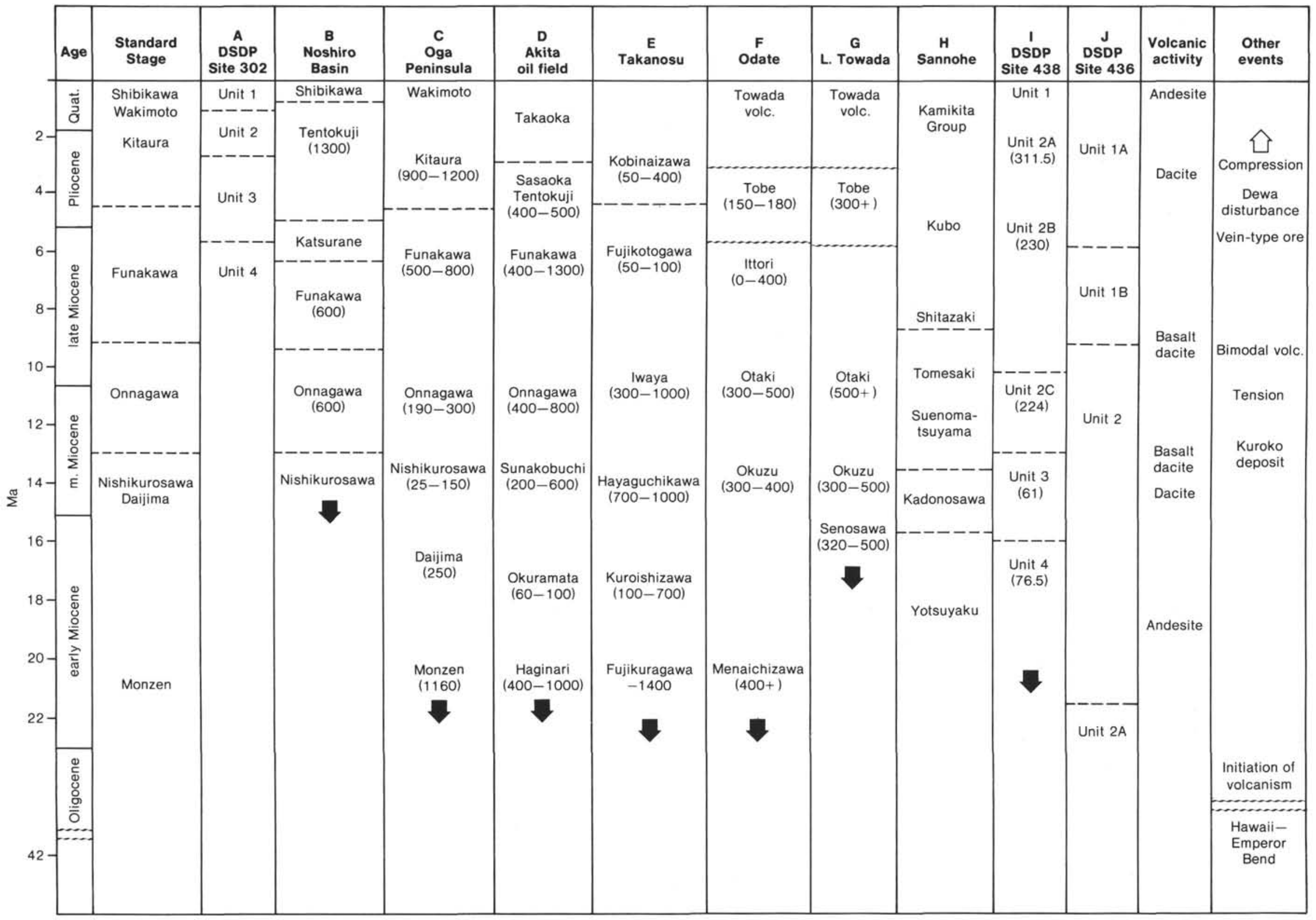

Figure 16. Stratigraphy across the Tohoku Arc from west to east, along $40^{\circ} \mathrm{N}$ latitude. Areas A through $\mathrm{J}$ are located in Figure 15 . Numbers written below the formation names give sediment thicknesses in meters. References: A, the Sea of Japan (Ingle, Karig, et al., 1975); B, Noshiro Basin (Suzuki, 1979); C, Oga Peninsula (Kitazato, 1975; Takayasu and Matoba, 1976); D, Akita Basin (Huzioka et al., 1977); E, Takanosu region (Hirayama and Sumi, 1963); F, Hokuroku region (Inoue et al., 1973a); G, Sekiryo Range (backbone range, Inoue et al., 1973); H, Sannohe region (Hayakawa et al., 1954; Chinzei, 1958a, b, 1966); I, DSDP Site 438 (Shipboard Scientific Party, 1980a, b); J, Pacific basin (Shipboard Scientific Party, 1980a, b). 


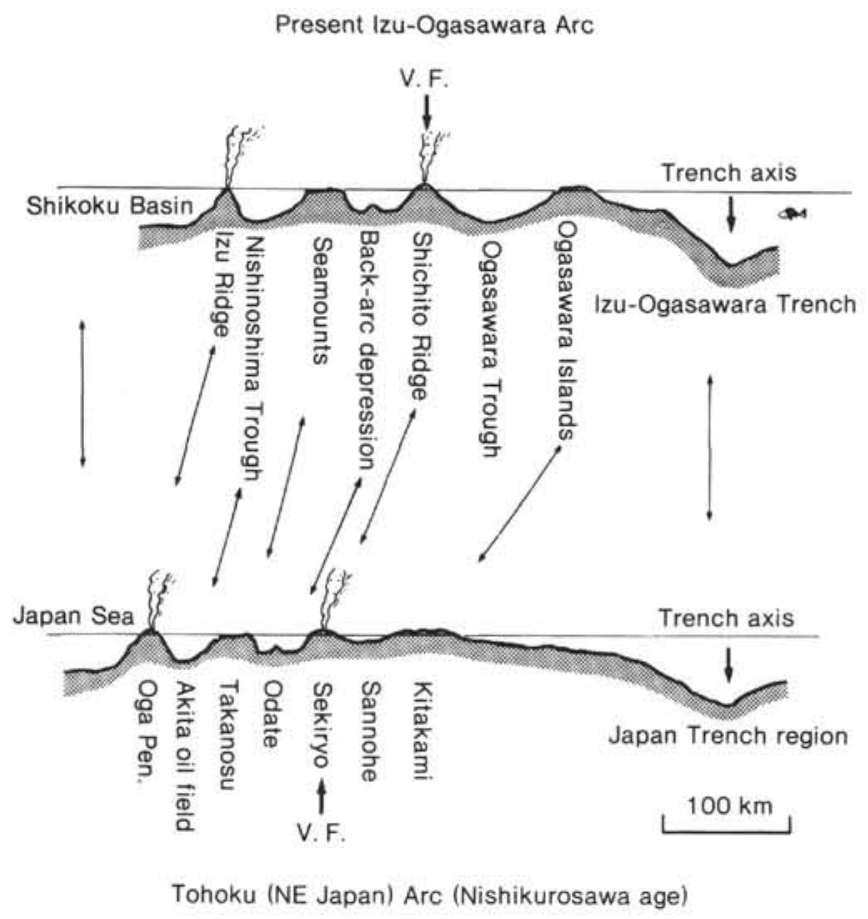

Figure 17. Schematic cross sections of the Tohoku Arc and the IzuOgasawara Arc. Tie lines show the correspondence between the morphotectonic elements of the two arcs; note the similarity. V.F. $=$ volcanic front.

regularly from bottom to top of the section, recording the approach of Site 436 to the Tohoku Arc through out the Neogene (Fig. 18). Chemical analyses show that the tephra derive from magmas of the calc-alkalic and/or tholeiitic series, the predominant magma type(s) in the island-arc and active continental-margin settings.

5. Chemical analyses show that the tephra derive from magmas of the calc-alkalic and/or tholeiitic series, the predominant magma type(s) in the island-arc and continental-margin settings.

6. Compilation of the history of volcanic activity of Neogene Tohoku Arc are well correlated to the marine and onshore volcanic maxima.

7. Marine volcanogenic sediments make up the "fossil" record of explosive volcanism in the Tohoku Arc, and the episodes are concentrated in the Daijima-Nishikurosawa stages (16-15 Ma) and the Funakawa-Kitaura stages (5-2 Ma).

8. The regional acidic volcanic activity of $16-15 \mathrm{Ma}$ (Fig. 19) was closely related to the formation of the Koroku deposits. Activity in the 5-2 Ma interval was closely related to the vein-type ore deposits and to the intrusion of Tertiary granitoids and resultant uplift of the Tohoku Arc.

\section{ACKNOWLEDGMENTS}

To Prof. N. Nasu, Drs. R. von Huene, J. P. Cadet, J. Barron, F. Akiba, M. Arthur, K. Kobayashi, K. Nakamura, and H. Kagami, for their invaluable suggestions on the geology and geophysics of the volcanogenic sediments, and to Mrs. T. Furuta, K. Koga, Mrs. C. Harayama, for their assistance during the preparation of this chapter, I express my sincere thanks.

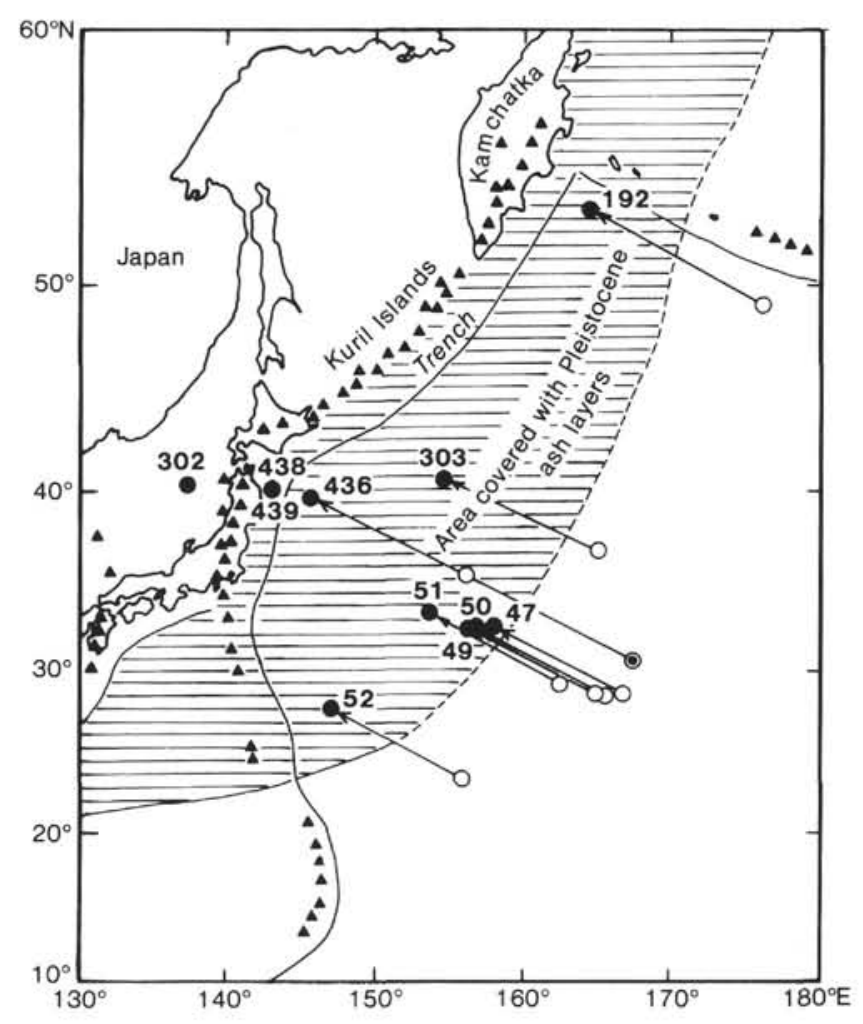

Figure 18. Relation between the ash zone and the movements of the Pacific Plate (after Ninkovich and Donn, 1976). Solid circle = present site; open circle $=$ site $10 \mathrm{Ma}$; double circle $=$ site $20 \mathrm{Ma}$. Hatched area is Quaternary ash zone defined by Ninkovich and Donn (1976). Solid triangles show the Quaternary active volcanoes.

West

East
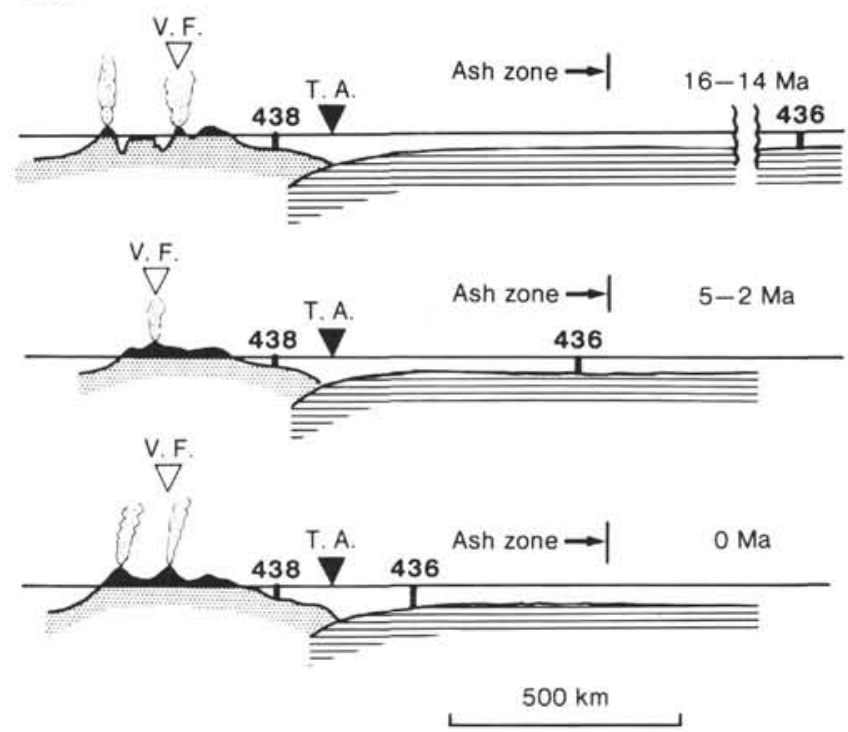

Figure 19. Schematic cross sections of the Tohoku Arc at various ages. V.F. $=$ volcanic front; T.A. $=$ trench axis. 


\section{REFERENCES}

Akiba, F., 1982. Taxonomy and biostratigraphic significance of a new diatom, Thalassionema schraderi. Bacillaria, 5:43-61.

Amano, K., 1981. Geology of the Ou backbone ranges in Miyagi and Yamagata prefectures, northeast Honshu, Japan. Sci. Rep. Tohoku Univ., Ser. 3, 81:1-56.

1983. Miocene geology of Seki district, Miyagi Prefecture, northeast Japan-block faulting in Miocene. J. Geol. Soc. Jpn., $89: 41-53$.

Arthur, M. A., Carson, B., and von Huene, R., 1980. Initial tectonic deformation of hemipelagic sediment at the leading edge of the Japan convergent margin. In Scientific Party, Init. Repts. DSDP, 56, 57, Pt. 1: Washington (U.S. Govt. Printing Office), 569-613.

Arthur, M. A., von Huene, R., and Adelseck, C. G., Jr., 1980. Sedimentary evolution of the Japan forearc region off northern Honshu, Legs 56 and 57, Deep Sea Drilling Project. In Scientific Party, Init. Repts. DSDP, 56, 57, Pt. 1: Washington (U.S. Govt. Printing Office), 521-568.

Barron, J. A., 1980. Lower Miocene to Quaternary diatom biostratigraphy of Leg 57, off northeast Japan, Deep Sea Drilling Project. In Scientific Party, Init. Repts. DSDP, 56, 57, Pt. 2: Washington (U.S. Govt. Printing Office), 641-685.

Barron, J. A., Harper, H. E., Jr., Keller, G., Reynolds, R. A., Sakai, T., Shaffer, B. L., and Thompson, P. R., 1980. Biostratigraphic summary of the Japan Trench transect, Legs 56 and 57, Deep Sea Drilling Project. In Scientific Party, Init. Repts. DSDP, 56, 57, Pt. 1: Washington (U.S. Govt. Printing Office), 505-520.

Bowles, F. A., Jack, R. N., and Carmichael, I. S. E., 1973. Investigation of deep-sea volcanic ash layers from equatorial Pacific cores. Geol. Soc. Am. Bull., 84:2371-2388.

Bramlette, M. N., and Bradley, W. H., 1941. Geology and biology of North Atlantic deep-sea cores between Newfoundland and Ireland, Part I. Lithology and geological interpretation. Geol. Surv. Prof. Pap. U.S., 196-A:1-55.

Cadet, J. P., and Fujioka, K., 1980. Neogene volcanic ashes and explosive volcanism: Japan Trench transect, Leg 57, Deep Sea Drilling Project. In Scientific Party, Init. Repts. DSDP, 56, 57, Pt. 2: Washington (U.S. Govt. Printing Office), 1027-1041.

Carey, S. N., and Sigurdsson, H., 1978. Deep-sea evidence for distribution of tephra from the mixed magma eruption of the Soufriére on St. Vincent, 1902: ash turbidites and air fall. Geology, 6: 271-274.

Chinzei, K., 1958a. On the Neogene formations in the vicinity of Fukuoka-machi, Iwate Prefecture-Cenozoic geology of the northern margin of the Kitakami Mountains, I. J. Geogr., 67:1-30.

$1958 \mathrm{~b}$. Pliocene stratigraphy of the northern margin of the Kitakami Mountains, northeast Japan-Cenozoic geology of the northern margin of the Kitakami Mountains, II. J. Geol. Soc. Jpn., 64:526-536.

1966. Younger Tertiary geology of the Mabechi River valley, northeast Honshu, Japan. J. Fac. Sci. Univ. of Tokyo, Ser. 2, 16:161-208.

1978. Neogene molluscan faunas in the Japanese Islands: An ecologic and zoogeographic synthesis. The Veliger, 21:155-170.

Dickinson, W. R., 1973. Widths of modern arc-trench gaps proportional to past duration of igneous activity in associated magmatic arcs. J. Geophys. Res., 78:3376-3389.

Dickinson, W. R., and Seely, D. R., 1979. Structure and stratigraphy of the forearc regions. Am. Assoc. Pet. Geol. Bull., 63:2-31.

Fisher, R. V., 1963. Bubble-wall texture and its significance. J. Sediment. Petrol., 33:224-227.

Fujioka, K., 1980. Conglomerates of volcanic rocks of Deep Sea Drilling Project Site 439. In Scientific Party, Init. Repts. DSDP, 56, 57, Pt. 2: Washington (U.S. Govt. Printing Office), 1075-1082.

1983a. History of the explosive volcanism of the Tohoku Arc from the core sediment samples of the Japan Trench. J. Volcanol. Soc. Jpn., 28:41-58.

1983b. Where were the "Kuroko deposits" formed? Looking for the present-day analogy. Mining Geol., Spec. Issue, 11; 55-68.

Fujioka, K., Furuta, T., and Arai, F., 1980. Petrography and geochemistry of volcanic glass: Leg 57, Deep Sea Drilling Project. In
Scientific Party, Init. Repts. DSDP, 56, 57, Pt. 2: Washington (U.S. Govt. Printing Office), 1049-1066.

Fujioka, K., Furuta, Kong, Y., Nishimura, A., Shiki, T., and Nasu, N., 1980. Sampling of the bottom sediments by piston coring. In Nasu, N., and Kobayashi, K. (Eds.), Preliminary Cruise Report, KH 77-1: Tokyo (Ocean Research Institute, Univ. of Tokyo), 75-109.

Fujioka, K., and Nasu, N., 1978. Chemical composition of the volcanic rocks from the Oyashio ancient landmass. EOS, Trans. Am. Geophys. Union, 59:1183-1184.

Hayakawa, N., Funayama, Y., Saito, K., and Kitamura, N., 1954. Geology of Neogene system from the western margin of the Kitakami Mountains to backbone ranges, Iwate Prefecture, Japan. Tohoku Kozan, 10:1-90.

Hirayama, J., and Sumi, K., 1960. Explanatory text of the geological map of Japan: Takanosu sheet (scale 1:50,000): Kawasaki (Geol. Surv. Jpn.), pp. 1-90.

Honza, E., 1980. Presite survey of the Japan Trench transect, Deep Sea Drilling Project. In Scientific Party, Init. Repts. DSDP, 56, 57, Pt. 1: Washington (U.S. Govt. Printing Office), 449-458.

Honza, E., Kagami, H., and Nasu, N., 1977. Neogene geological history of the Tohoku Island Arc system. J. Oceanogr. Soc. Jpn., 33: 297-310.

Horikoshi, E., 1975. Genesis of Kuroko-Stage deposits from the tectonic point of view. J. Volcanol. Soc. Jpn., 20:341-353.

1976. Development of late Caenozoic petrogenic provinces and metallogeny in northeast Japan. Spec. Pap. Geol. Assoc. Canada, 14:121-142.

Horn, D. R., Delach, M. N., and Horn, B. N., 1969. Distribution of volcanic ash layers and turbidites in the North Pacific. Geol. Soc. Am. Bull., 80:1715-1724.

Huang, T. C., Watkins, N. D., and Shaw, D. M., 1975. Atmospherically transported volcanic glass in deep-sea sediments: Volcanism in sub-Antarctic latitudes of the South Pacific during late Pliocene and Pleistocene time. Geol. Soc. Am. Bull., 86:1305-1315. 1979. Atmospherically transported volcanic glass in deepsea sediments: Development of a separation and counting technique. Deep-Sea Res., 22:185-196.

Huzioka, K., 1956. Studies of the green tuff. Kagaku, 26:440-446. 1968. The Dewa disturbance in Akita oil field. J. Jpn. Assoc. Petrol. Tech., 33:283-297.

Huzioka, K., Ozawa, A., Takayasu, T., and Ikebe, Y., 1977. Geology of the Akita District: Tokyo (Geol. Surv. Japan), Quadrangle Series, scale 1:50,000.

Ikebe, Y., 1962. Tectonic developments of oil-bearing Tertiary and migrations of oil in Akita oil fields, Japan. Rep. Res. Inst. Underground Resources, Mining Coll., Akita Univ., 26:1-59.

Ingle, J. C., Jr., Karig, D. E., and Shipboard Scientific Party, 1975. Site 299. In Karig, D. E., Ingle, J. C., Jr., et al., Init. Repts. DSDP, 31: Washington (U.S. Govt. Printing Office), 351-402.

Inoue, T., Noritani, K., Ueda, R., and Usuda, M., 1973a. Explanatory text of the geological map of Akita Prefecture: Hanawa sheet (scale 1:50,000). Akita Pref., 1-54.

1973b. Explanatory text of the geological map of Akita Prefecture: Odate sheet (scale 1:50,000). Akita Pref., 1-94.

Ishihara, S., 1974. Magmatism of the green tuff tectonic belt, northeast Japan. Mining Geol., Spec. Issue, 6:235-249.

Jordan, C. F., Jr., Fryer, G. E., and Hemmen, E., 1971. Size analysis of silt and clay by hydrophotometer. J. Sediment. Petrol., 41: 489-496.

Kanamori, H., 1971. Great earthquake at island arc and the lithosphere. Tectonophysics, 12:187-198.

Kaneoka, I., 1983. On the radiometric ages of volcanic rocks from the northeastern part of Honshu Island, Japan. Mining Geol., Spec. Issue, 11:69-78.

Kawano, Y., Yagi, K., and Aoki, K., 1961. Petrography and petrochemistry of the volcanic rocks of Quaternary volcanoes of northeastern Japan. Sci. Rep. Tohoku Univ., Ser. 3, 6:1-46.

Keller, G., 1980. Benthic foraminifers and paleobathymetry of the Japan Trench area, Leg 57, Deep Sea Drilling Project. In Scientific Party, Init. Repts. DSDP, 56, 57, Pt. 2: Washington (U.S. Govt. Printing Office), 835-865.

Kennett, J. P., 1981. Marine tephrochronology. In Emiliani, C. (Ed.), The Sea, Vol. 7: London (Academic Press), 1373-1436. 
Kennett, J. P., and Thunell, R. C., 1975. Global increase in Quaternary explosive volcanism. Science, 187:497-503.

Kennett, J. P., and Watkins, N. D., 1970. Geomagnetic polarity change, volcanic maxima and faunal extinction in the South Pacific. $\mathrm{Na}$ ture, 227:930-934.

Kitamura, N., 1959. Tertiary orogenesis in northeast Honshu, Japan. Sci. Rep. Tohoku Univ., Ser 3, 49:1-98.

Kitazato, H., 1975. Geology and geochronology of the younger Cenozoic of Oga Peninsula. Contr. Inst. Geol. Pal., Tohoku Univ., 75: $17-49$.

Kittleman, L. R., 1973. Mineralogy, correlation, and grain-size distributions of Mazama tephra and other postglacial pyroclastic layers, Pacific Northwest. Geol. Soc. Am. Bull., 84:2957-2980.

Koizumi, I., Barron, J. A., and Harper, H. E., Jr., 1980. Diatom correlation of Legs 56 and 57 with onshore sequences in Japan. In Scientific Party, Init. Repts. DSDP, 56, 57, Pt. 2: Washington (U.S. Govt. Printing Office), 687-694.

Konda, T., 1974. Bimodal volcanism in the Northeast Japan arc. $J$. Geol. Soc. Jpn., 80:81-89.

Konda, T., and Ueda, Y., 1980. K-Ar age of the Tertiary volcanic rocks in the Tohoku area, Japan. J. Jpn. Assoc. Min. Petrol. Econ. Geol., Spec. Issue, 2:343-346.

Kuno, H., 1960. High alumina basalt. J. Petrol., 1:121-145.

1965. Fractionation trends of basalt magmas in lava flows. J. Petrol., 6:302-321.

1966. Lateral variation of basalt magma type across continental margins and island arcs. Bull. Volcanol., 29:195-222.

Lancelot, Y., and Larson, R. L., 1975. Sedimentary and tectonic evolution of northwestern Pacific. In Larson, R. L., Moberly, R., et al., Init. Repts. DSDP, 32: Washington (U.S. Govt. Printing Office), 925-939.

Langseth, M. G., and Shipboard Scientific Party, 1978. Transect begun. Geotimes, 23(3):22-26.

Langseth, M. G., von Huene, R., Nasu, N., and Okada, H., 1980. Subsidence of the Japan Trench forearc region of northern Honshu. Oceanol. Acta., Spec. Issue, 173-179.

Leg 87 Scientific Party, 1983. Leg 87 drills off Honshu and SW Japan. Geotimes, 28(1):15-18.

Lisitzin, A. P., 1972. Sedimentation in the World Ocean. Soc. Econ. Paleontol. Mineral. Spec. Publ., 17.

Ludwig, W. J., Ewing, J. I., Ewing, M., Murauchi, S., Den, N., Asano, S., Hotta, H., Hayakawa, M., Asanuma, T., Ichikawa, K., and Noguchi, I., 1966. Sediment and structure of the Japan Trench. $J$. Geophys. Res., 71:2121-2137.

Machida, H., 1981. Tephrochronology and Quaternary studies in Japan. In Self, S., and Sparkes, R. S. J. (Eds.), Tephra Studies: Boston, London (D. Reidel Pub. Co.), pp. 161-191.

Machida, H., and Arai, F., 1976. The very widespread tephra-the Aira-Tn ash. Kagaku, 46:339-347.

Matsuda, T., and Nakamura, K., 1970. Sedimentary features of waterlaid volcanic deposits and their classification based on mode of emplacement. Mining Geol., 20:29-42.

Matsuda, T., Nakamura, K., and Sugimura, A., 1967. Late Cenozoic orogeny in Japan. Tectonophysics, 4:349-366.

Matsuda, T., and Uyeda, S., 1971. On the Pacific type orogeny and its model-extrusion of the paired belts concept and possible origin of marginal seas. Tectonophysics, 11:5-27.

Matsumoto, R., and Iijima, A., 1980. Carbonate diagenesis in cores from Sites 438 and 439 off northeast Honshu, northwest Pacific, Leg 57, Deep Sea Drilling Project. In Scientific Party, Init. Repts. DSDP, 56, 57, Pt. 2: Washington (U.S. Govt. Printing Office), 1117-1131.

Miyashiro, A., 1967. Orogeny, regional metamorphism and magmatism in the Japanese Islands. Medd. Dansk. Geol. Foren., 17:390446.

1972a. Metamorphism and related magmatism in plate tectonics. Am. J. Sci., 272:629-650.

$1972 \mathrm{~b}$. Pressure and temperature conditions and tectonic significance of regional and ocean-floor metamorphism. Tectonophysics, 13:141-159.

1974. Volcanic rock series in island arcs and active continental margins. Am. J. Sci., 274:321-355.

1975. Volcanic rock series and tectonic setting. Earth Planet. Sci. Lett., Ann. Rev., 6:251-269.
Moore, G. W., and Fujioka, K., 1980. Age and origin of dacite boulder conglomerate anomalously near the Japan Trench. In Scientific Party, Init. Repts. DSDP, 56, 57, Pt. 2: Washington (U.S. Govt. Printing Office), 1083-1088.

Murai, I., 1963. Pyroclastic flow deposits on various volcanoes in Japan. Bull. Volcanol., 26:337-351.

Murauchi, S., Asanuma, T., Taguchi, H., Kinoshita, H., Yokoyama, I., Nakatani, H., and Tanaka, K., 1978. Crustal structure of the island arc slope and the trench off Sanriku and mechanism of subduction. Mar. Sci., 10:207-214.

Murauchi, S., and Ludwig, W., 1980. Crustal structure of the Japan Trench: the effect of subduction of ocean crust. In Scientific Party, Init. Repts. DSDP, 56, 57, Pt. 1: Washington (U.S. Govt. Printing Office), 463-469.

Nakamura, K., and Uyeda, S., 1980. Stress gradient in arc-backarc regions and plate subduction. J. Geophys. Res., 85:6419-6428.

Nasu, N., 1964. The provenance of the coarse sediments on the continental shelves and the trench slopes off the Japanese Pacific coast. In Miller, R. L. (Ed.), Papers in Marine Geology: New York (Macmillan Co.), pp. 65-101.

Nasu, N., Iijima, A., and Kagami, H., 1960. Geological results in the Japanese Deep Sea Expedition in 1959. Oceanog. Mag., 11: 201-214.

Nasu, N., and Sato, T., 1962. Geological results in the Japanese Deep Sea Expedition in 1961 (JEDS-4). Oceanol. Mag., 13:155-166.

Niitsuma, N., 1978. Magnetic stratigraphy of the Japanese Neogene and the development of the island arcs of Japan. J. Phys. Earth, 26(Suppl.):367-378.

Ninkovich, D., and Donn, W. L., 1976. Explosive Cenozoic volcanism and climatic interpretations. Science, 194:899-906.

Ninkovich, D., and Shackleton, N .J., 1975. Distribution, stratigraphic position and age of ash layer " $\mathrm{L}$ " in the Panama Basin region. Earth Planet. Sic. Lett., 27:20-34.

Ozawa, A., 1963. Neogene orogenesis, igneous activity and mineralization in the central part of northeast Honshu. (1) On the Neogene igneous activity. J. Jpn. Assoc. Mineral. Petrol. Econ. Geol., 50:167-184.

Sakuyama, M., 1979. Lateral variation of $\mathrm{H}_{2} \mathrm{O}$ contents in Quaternary magmas of northeastern Japan. Earth Planet. Sic. Lett., 43: 103-111.

Sato, T., 1973. Several considerations on the Deep Sea Plains. Mar. Sci., 5:703-707.

Shipboard Scientific Party, 1980a. Sites 438 and 439, Japan deep sea terrace, Leg 57. In Scientific Party, Init. Repts. DSDP, 56, 57, Pt. 1: Washington (U.S. Govt. Printing Office), 23-191.

Shipboard Scientific Party, 1980b. Site 436, Japan Trench outer rise, Leg 56. In Scientific Party, Init. Repts. DSDP, 56, 57, Pt. 1: Washington (U.S. Govt. Printing Office), 399-446.

Sugimura, A., Matsuda, T., Chinzei, K., and Nakamura, K., 1963. Quantitative distribution of late Cenozoic volcanic materials in Japan. Bull. Volcanol., 26:125-140.

Suzuki, U., 1979. Petroleum geology of the Sea of Japan, northern Honshu. J. Jpn. Assoc. Petrol. Tech., 44:59-75.

Takayasu, T., Matoba, Y., Huzioka, K., et al., 1976. Guidebook for Excursion 1, Oga Peninsula: Tokyo (Int. Congr. Pac. Neo. Stratigr.).

Takeuchi, A., 1981. Temporal changes of regional stress field and tectonics of sedimentary basin. J. Geol. Soc. Jpn., 87:737-751.

Tamaki, K., in press. Two modes of back-arc spreading. Geology.

Tatsumi, T., and Clark, L. A., 1972. Chemical composition of acid volcanic rocks genetically related to formation of the Kuroko deposits. J. Geol. Soc. Jpn., 78:191-201.

Thompson, P. R., and Whelan, J. K., 1980. Fecal pellets at Deep Sea Drilling Project Site 436. In Scientific Party, Init. Repts. DSDP, 56, 57, Pt. 2: Washington (U.S. Govt. Printing Office), 921-935.

Togashi, S., 1983. Temporal and spatial variation of alkali elements in Miocene igneous rocks of northern Honshu, Japan. Mining Geol., Spec. Issue, 11:93-102.

Tsuchi, R., 1979. Japanese Neogene Bio- and Chronostratigraphy: Osaka (IGCP-114, National Working Group of Japan).

Uyeda, S., 1982. Subduction zones: an introduction to comparative subductology. Tectonophysics, 81:133-159.

Uyeda, S., and Miyashiro, A., 1974. Plate tectonics and the Japanese Islands: A synthesis. Geol. Soc. Am. Bull., 85:1159-1170. 
Vallier, T. L., and Kidd, R. B., 1977. Volcanogenic sediments in the Indian Ocean. In Heirtzler, J. R., Bolli, H. M., Davies, T. A., Saunders, J. B., and Sclater, J. G. (Eds.), Indian Ocean Geology and Biostratigraphy. Studies Following Deep-Sea Drilling Legs 2229: Washington (Am. Geophys. Union), pp. 87-118.

von Huene, R., Langseth, M., Nasu, N., and Okada, H., 1982. A summary of Cenozoic tectonic history along the IPOD Japan Trench transect. Geol. Soc. Am. Bull., 93:826-846.

von Huene, R., and Shipboard Scientific Party, 1978. Japan Trench transected. Geotimes, 23(4):16-21.

von Huene, R., and Uyeda, S., 1980. A summary of results from the IPOD transects across the Japan, Mariana, and Middle-America convergent margins. Oceanol. Acta, Spec. Issue No. 4, 233-239.
Yanagisawa, M., Takigami, Y., Ozima, M., and Kaneoka, I., 1980. ${ }^{40} \mathrm{Ar} /{ }^{39} \mathrm{Ar}$ ages of boulders drilled at Site 439, Leg 57, Deep Sea Drilling Project. In Scientific Party, Init. Repts. DSDP, 56, 57, Pt. 2: Washington (U.S. Govt. Printing Office), 1281-1284.

Yoshii, T., 1979. A detailed cross-section of the deep seismic zone beneath northeastern Honshu, Japan. Tectonophysics, 55:349-360.

Date of Initial Receipt: 25 June 1984 Date of Acceptance: 13 May 1985 


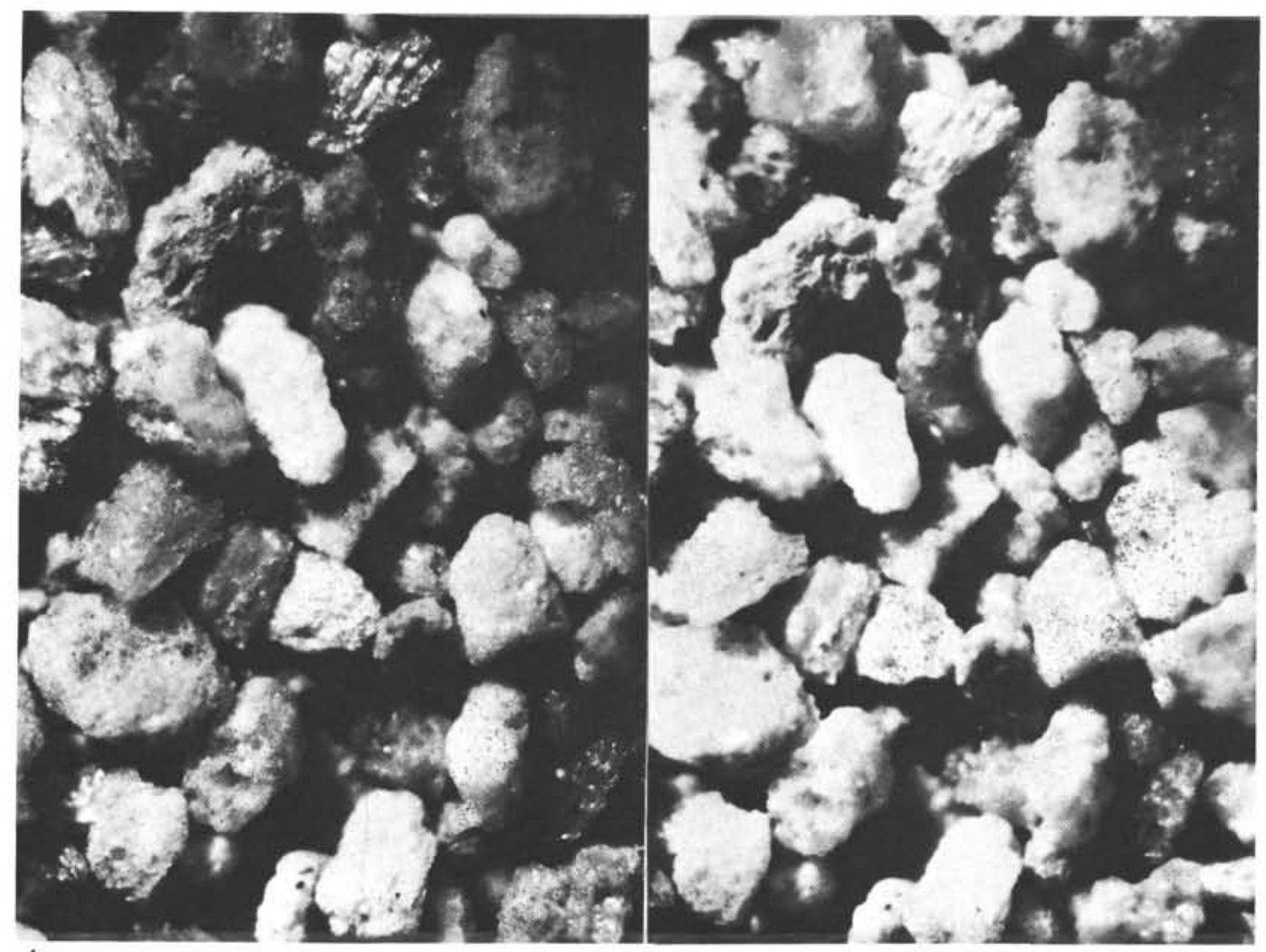

1

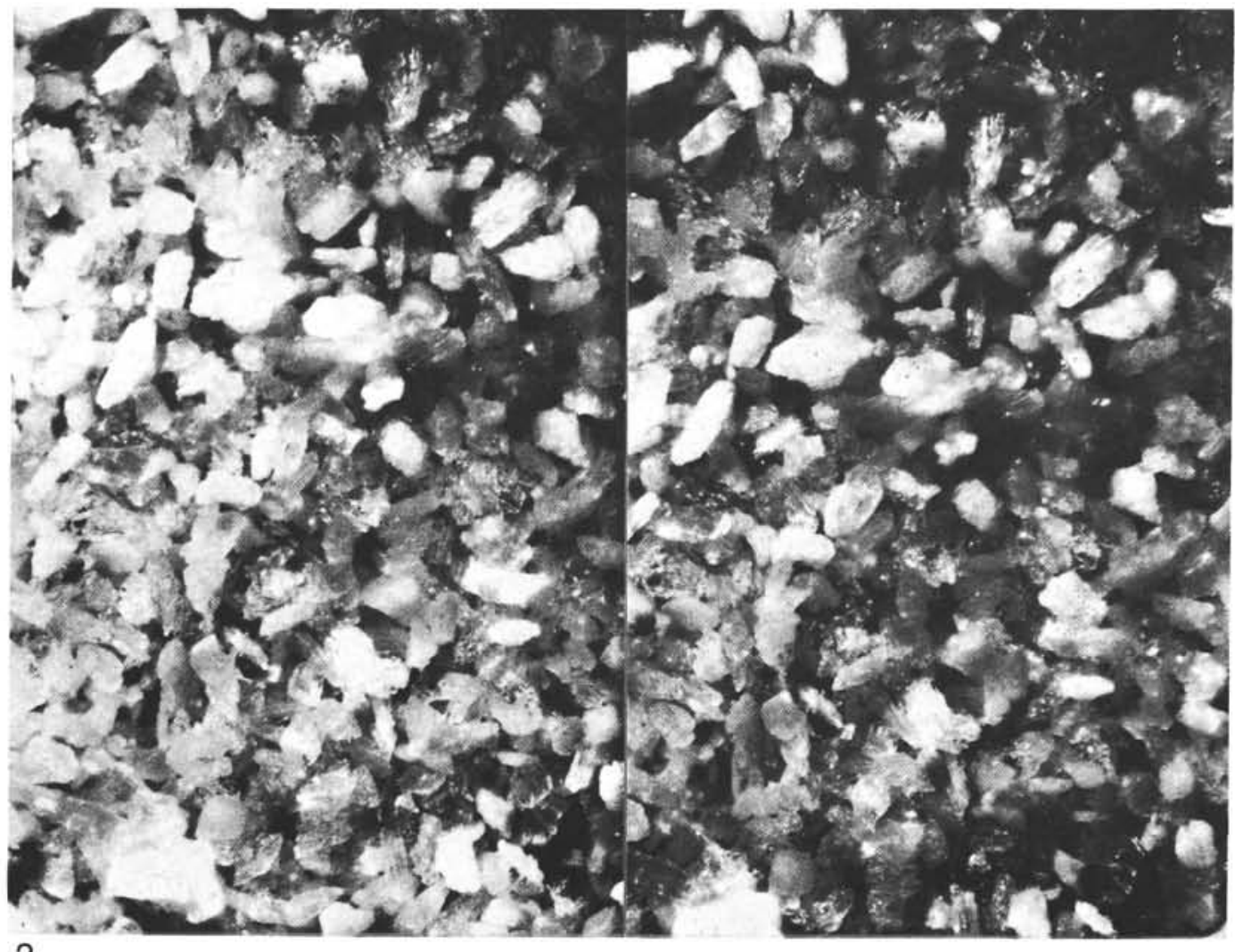

Plate 1. Stereographic photos of volcanic ash layers from Hole 438A. (Scale is about $5 \mathrm{~mm}$ from top to bottom of each photo.) 1. Sample $438 \mathrm{~A}-1-1,10-11 \mathrm{~cm}$. 2. Sample 438A-6-4, 22-23 cm. 


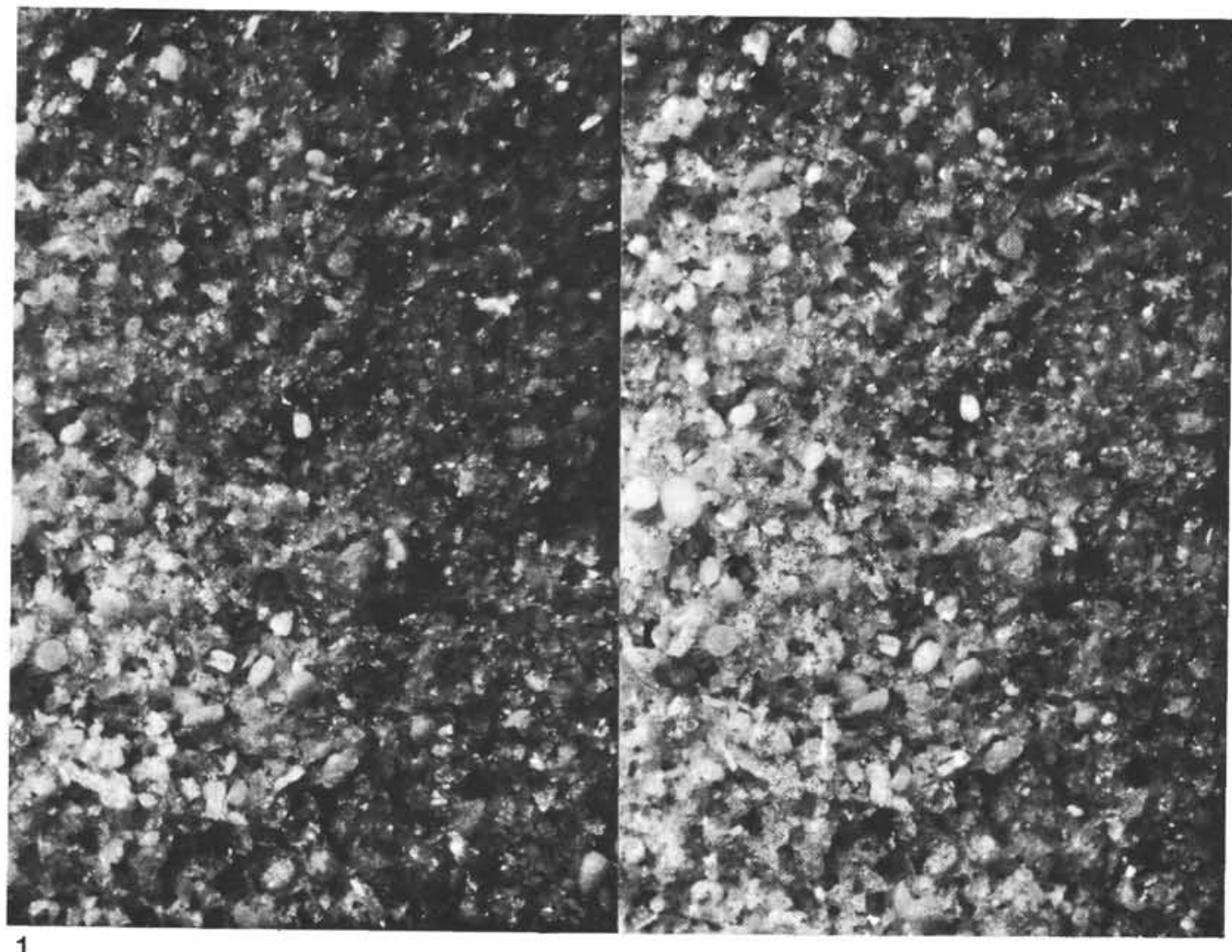

1

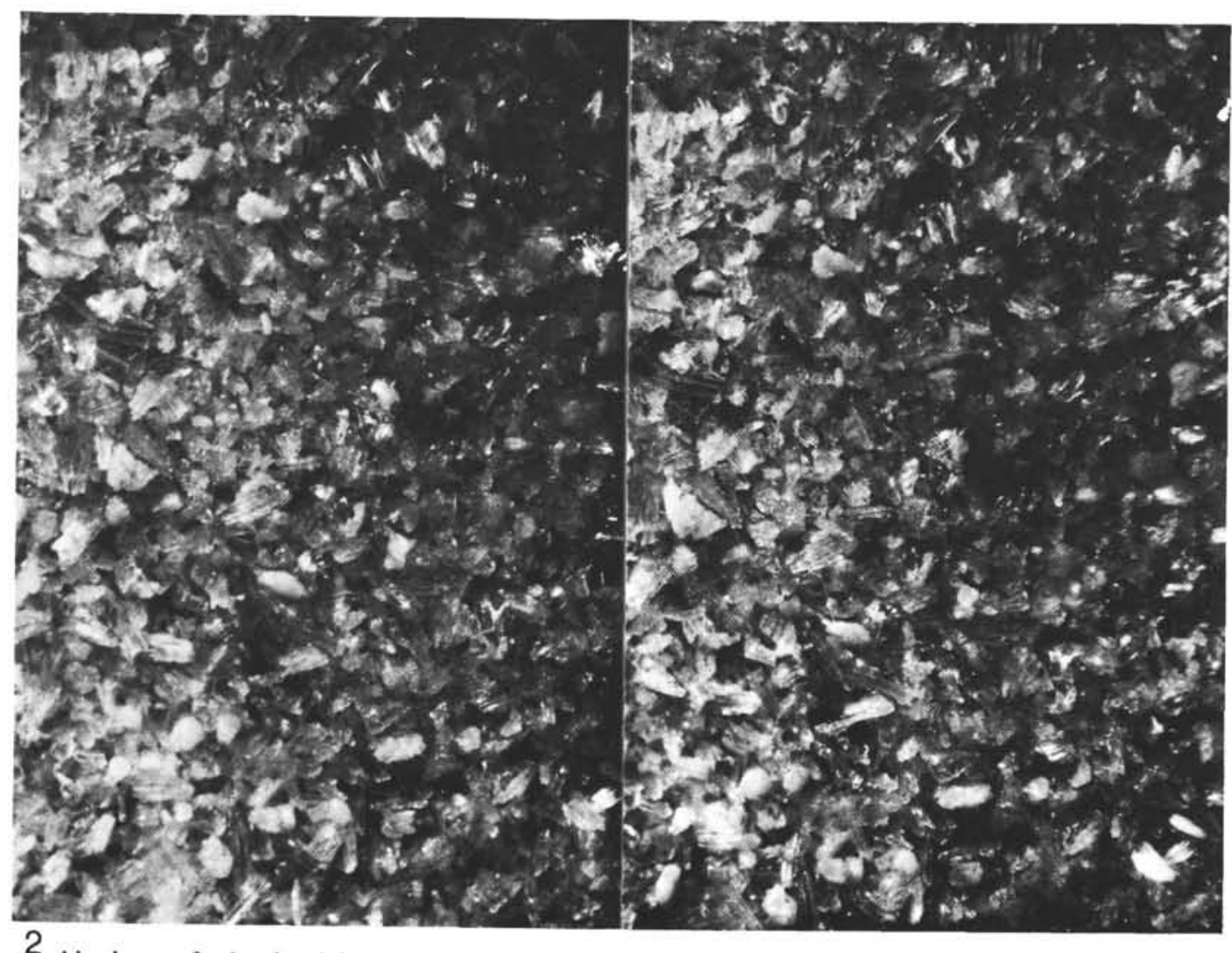

Plate 2. Stereographic photos of volcanic ash layers from Hole 436. (Scale is about $5 \mathrm{~mm}$ from top to bottom of each photo.) 1. Sample 436-9-2, $89-91 \mathrm{~cm}$. 2. Sample 436-10-1, 60-62 cm. 